\title{
Birleşme Amaçlı Ortaklıklar ve Hedef Şirketle Birleşmesine İlişkin Özellik Arz Eden Durumlar
}

\author{
Special Purpose Acquisition Companies and Specific Circumstances \\ Regarding Their Merger with Target Companies
}

Nevin Meral ${ }^{* *}$ (D)

\section{öz}

Özel amaçlı devralma şirketleri (SPACs) veya Türk hukukunda düzenlendiği şekliyle birleşme amaçlı ortaklıklar, son yıllarda uluslararası piyasalarda oldukça yoğun bir şekilde talep görmektedir. ABD SPAC’leri model alınan ve bu çalışmanın konusunu oluşturan birleşme amaçlı ortaklıkların halka arzdan önce kendine ait hiçbir ticari faaliyeti yoktur ve bu ortaklıklar, halka açık olmayan, halihazırda ticari faaliyette bulunan ve hedef şirket olarak adlandırılan bir şirketle birleşmek üzere halka arz yoluyla kurulurlar. Bu süreç, kendi içinde bazı riskler barındırmaktadır. Hedef şirketler, halka açılmaya ilişkin sermaye piyasası düzenlemelerine uyumun zor olduğu düşüncesiyle ve bu düzenlemeleri dolanma sonucunu doğuracak şekilde, birleşme amaçlı ortaklık ile birleşmek istemektedir. Dolayısıyla birleşme işleminin, geleneksel halka arz işlemlerine nazaran daha kolay olması ve daha erken bir zamanda halka açık şirket olması imkânı, hedef şirketlerin birleşme amaçlı ortaklıklar ile birleşme talebini artırmaktadır. Bir halka arzın başarılı olmama riski, bu tür ortaklıklarla birleştiklerinde ortadan kalkacak ve küçük bir şirket olan hedef şirkete nakit akışının sağlanmasını garantiye alacaktır.

Birleşme amaçlı ortaklıklar, halka arz izahnamesinde belirlenmiş bir süre içinde ve yatırım stratejisi doğrultusunda bir hedef şirket bularak birleşmek durumundadır. Ancak gerek birleşmenin bir sebeple gerçekleşmemesine bağlı olarak gerekse birleşmenin, birleşme amaçlı ortaklığın genel kurulunda kabul edilmesine rağmen bu birleşmeden hoşnut olmadıkları için bazı pay sahiplerinin ayrılmak istemesi mümkündür. Belirlenen süre sonunda birleşmenin gerçekleşmemesi halinde halka arzdan elde edilen gelirin \%90’ının kurucular dışındaki pay sahiplerine geri verilmesi söz konusu olacaktır. Diğer durumda ise, birleşmenin gerçekleşmesine rağmen şirketten ayrılmak isteyen pay sahiplerine yönelik gönüllü geri alım işleminin uygulanması gerekmektedir. Bu durumda gönüllü geri alım işleminin nasıl işleyeceğinin ayrıntılı bir şekilde irdelenmesi gerekmektedir.

Anahtar Kelimeler: Birleşme, Birleşme amaçlı ortaklıklar, Gönüllü geri alım, Hedef şirket, Paylarda sulanma.

* $\quad$ Bu makalenin konusu, Asos 7. Uluslararası Hukuk Sempozyumu’nda Tebliğ olarak sunulmuştur.

** Doktor Öğretim Üyesi, Ankara Yıldırım Beyazıt Üniversitesi Hukuk Fakültesi, Ticaret Hukuku Anabilim Dalı, ORCID: 0000-0001-6205-2680

Sorumlu Yazar/Correspondence Author: Nevin Meral

E-posta/E-mail: nmeral@ybu.edu.tr

Geliş Tarihi/Received: $\quad$ 12.09.2021

Kabul Tarihi/Accepted:

05.11.2021 


\section{ABSTRACT}

SPACs or 'birleşme amaçlı ortaklıklar' as regulated in Turkish law, have burst in recent years in international markets. Turkish SPACs modelled after their US counterparts, are founded through the initial public offering (IPO), and do not have any commercial operation until then. SPACs seek to merge with an operating non-public company called as target company. However, this merger process has its own risks. Bearing in mind that the IPO procedure is challenging, non-public companies may wish to merge with SPACs, by evading the relevant securities regulations. Hence, target companies seem to have an increasing demand to merge with SPACs, because merger procedure is easier to oblige than that of IPO's and they can become public in a shorter time. The merger with SPACs will diminish the failure risk in an IPO and ensure the cash flow into the target company, which is already financially small sized. Moreover, SPACs are obliged to merge with a target company within the timeframe and within the scope of investment strategy determined in their prospectuses in IPOs. However, some shareholders may wish to redeem their shares since the merger has not taken place for a reason or despite the shareholder approval of the merger, they are not satisfied of this merger. In case the merger has not consummated within the timeframe, the shareholders except sponsors are required to receive the $90 \%$ of the fund from the IPO must. In the other case, the voluntary buy-back process must be observed for the shareholders who would like to redeem their shares despite shareholder approval of the merger. Therefore, how this voluntary buy-back should be processed should be examined in detail.

Keywords: Merger, SPACs (special purpose acquisition companies), voluntary buy-back, target company, dilution in shares.

\section{Giriş}

Amerika Birleşik Devletleri (ABD) hukukuna ilk olarak 1900'lü yılların başında giriş yapan ve 2000'li yıllardan itibaren yoğun olarak kullanılan ${ }^{1}$ SPAC'leri (special purpose acquisition company: özel amaçlı devralma şirketi) model alan bir kavram Türk hukukuna da girmiştir. İlk kez 2013 yılında hukukumuzda düzenlenen birleşme amaçlı ortaklıklar, alternatif bir yatırım aracı ${ }^{2}$ olarak nitelendirilebilir. Son birkaç yılda ABD piyasasında tüm halka arzların yarısından daha fazlasının bu tür ortaklıklarca yapıldı̆̆ ${ }^{3}$ görülmüş olmakla birlikte bu dönem özellikle medyada bu şirketlerin

1 Milos Vulanovic, 'SPACs: Post-Merger Survival' (2017) 43(6) Managerial Finance 679, 680; Lora Dimitrova, 'Perverse Incentives of Special Purpose Acquasition Companies, 'the Poor Man's Private Equity Funds" (2017) 63 Journal of Accounting and Economics 99, 99; Niharika Anand 'Special Purpose Acquisition Company' (2020) 7 (4) Court Uncourt 21, 21; Kanis Saengchote, 'The Tesla Effect and the Mispricing of Special Purpose Acquisition Companies (SPACs)' $(S S R N, 2021)<$ https://ssrn.com/abstract=3800323> Erişim Tarihi 15 Ağustos 2021, s. 1; Elene Ignatyeva, Christian Rauch and Mark Wharenburg, 'Analysing European SPACs' (2013) 17(1) The Journal of Private Equity 64, 64; ancak SPAC'ler ABD hukukunda 2000'li yıllara kadar bu ölçüde dikkat çekmemiştir, Robert Berger, 'SPACs: An Alternative Way to Access the Public Markets' (2008) 20(3) Journal of Applied Corporate Finance 68, 68.

2 Berger (n 1) 68; Jessica Bai, Angela Ma and Miles Zheng, 'Reaching for Yield in the Going-Public Market: Evidence from SPACs' (SSRN, 2021) <https://ssrn.com/abstract=3746490> Erişim Tarihi 01 Eylül 2021, s. 1; Ignatyeva, Rauch and Wahrenburg (n 1) 64; Derin Altan ve Nil Acar, 'Yeni Bir Alternatif Yatırım Aracı: Birleşme Amaçlı Ortaklıklar' (2014), 16 (1) Dokuz Eylül Üniversitesi Hukuk Fakültesi Dergisi 251, 254. Birleşme amaçlı ortaklıkların, girişim sermayesi de dahil olmak üzere benzer kurumlarla karşılaştırılmasına ilişkin ayrıntılı bilgi için bkz. Gül Okutan Nilsson, Sermaye Piyasası Hukukunda Birleşme Amaçlı Ortaklık (On İki Levha, 2016) 5-17.

3 Sadece 2021 yılı için bile ABD’deki toplam ilk halka arzların \%70'inden fazla SPAC arzı yapılmıştır. İstatistikler için bkz. $<$ https://www.spacanalytics.com> Erişim Tarihi 20 Nisan 2021. 
niteliğine işaret ederek 'Açık Çek Patlaması' (blank check boom) olarak adlandırılmıştır. Nitekim Türk hukukunda birleşme amaçlı ortaklıklar olarak düzenlenen bu ortaklıklar, ${ }^{4}$ yatıımcıların kendisine birleşmek için şirket bulmak amacıyla adeta açık çek verdiklerini vurgulamak üzere açık çek şirketleri (blank check companies) ve halka arzdan önce hiçbir ticari faaliyeti veya varlığı olmamasını vurgulamak üzere ise kabuk şirketler (shell companies) gibi çeşitli isimlerle ${ }^{5}$ de anılmaktadır.

Birleşme amaçlı ortaklığın yaşam döngüsünü üç aşamada incelemek mümkündür. Bunlardan birincisi, kuruluşundan itibaren halka arzını da içeren ve hedef şirketin belirlenmesine kadar geçen süreç iken; ikincisi hedef şirketin belirlenmesinden sonra gerçekleşen birleşme süreci ve son olarak da birleşme amaçlı ortaklığın hedef şirketle birleşmesinden sonraki süreçtir. Birleşme amaçlı ortaklığın, deSPAC olarak da adlandırılan bu son aşaması, daha detaylı olarak, birleşmeden sonraki ilk iş gününden başlayarak şirketin farklı bir unvan ve ticker kodu altında piyasada işlem görmeye başlamasını ifade eder. ${ }^{6} \mathrm{Bu}$ çalışmamızda, birleşme amaçlı ortaklığın kuruluşu, halka arzı ve halka arzdan sonraki dönemde hedef şirketle birleşme gerçekleşene kadarki faaliyetlerinden oluşan birinci süreç, sadece gerektiği kadarıyla incelenecektir. Ancak çalışmanın konusu esas olarak birleşme amaçlı ortaklıkların ikinci aşaması olan, hedef şirketin belirlenmesi, ortaklıkta bu yönde karar alınması ve buna bağlı olarak gerçekleşebilecek geri alım sürecine ilişkindir.

Birleşme amaçlı ortaklıkların, hedef şrketleri belirlemesi, birleşme sürecinin başlaması ve birleşmenin gerçeklemesi durumlarında gerek kabuk şirket olmaları gerekse de sadece birleşme amacıyla kurulmaları dolayısıyla karşılaşabilecekleri bazı sorunların olduğu tartışmasızdır. Bunlara rağmen, yatırımcılar için oldukça ilgi çekici bir yatırım aracı olan ${ }^{7}$ birleşme amaçlı ortaklıklara ilişkin hususların, pay sahiplerinin yaşayabilecekleri sorunları karşısında, Türk sermaye piyasası mevzuatında nasıl düzenlendiği ve düzenlemelerin nasıl uygulanacağının ortaya koyulması gerekir. Bu kapsamda çalışmanın ilk kısmında birleşme amaçlı ortaklıkların tanımı ve özellikleri üzerinde

4 Türk hukukundaki bu tür ortaklıkların kökeninin SPAC’ler olduğuna yönelik olarak ayrıca bkz. Çağlar Manavgat, Hukuki Bakımdan Halka Açık Anonim Ortaklıklar ve Halka Arz (BTHAE, 2016) 580; Okutan Nilsson, 'Ortaklık' (n 2 ) 3.

5 SEC tarafından yapılan özelikle bu iki tür niteleme için bkz. SEC's Investor Bulletin, 10 December 2020, "What You Need to Know About SPACs" <https://www.sec.gov/oiea/investor-alerts-and-bulletins/what-you-need-know-aboutspacs-investor-bulletin>; <https://www.investor.gov/introduction-investing/ investing-basics/glossary/blank-checkcompany>; <https://www.sec.gov/corpfin/disclosure-special-purpose-acquisition-companies> Erişim Tarihi 24 Mayıs 2021. Ayrica bkz. Tim Jenkinson and Miguel Sousa, 'Why SPAC Investors Should Listen to the Market' (SSRN, 2009) <https://ssrn.com/abstract=1331383> Erişim Tarihi 20 Haziran 2021, s. 2; Nebojsa Dimic, Edward Lawrence and Milos Vulanovic, 'The Determinants of IPO Withdrawals: Evidence from SPACs' (SSRN, 2020) <https://ssrn.com/ abstract=3538671 > Erişim Tarihi 06 Eylül 2021, s. 4; Saengchote (n 1) 1; Ignatyeva, Rauch and Wahrenburg (n 1) 6465; Gül Okutan Nilsson, 'Incentive Structure of Special Purpose Acquisition Companies' (2018) 19 European Business Organisation Law Review 253, 253; Gökben Altaş, 'Satın Alma Amaçlı Şirketler' (2012) 12 TSPAKB Gündem 18, 22; Paul\&Weiss, Client Memorandum, 17 March 2021, "What SPAC Sponsors, Directors and Officers Can Do to Mitigate Their Litigation Exposure" <https://www.paulweiss.com/practices/litigation/securities-litigation/publications/whatspac-sponsors-directors-and-officers-can-do-to-mitigate-their-litigation-exposure?id=39540> Erişim Tarihi 26 Haziran 2021, s. 2. İlgili şirketlerin, açık çek şirketlere ilişkin 1990 yılında çıkarılan Penny Stock Act düzenlemelerinin kapsamına girmemesinin temel sebebi, paylarının ve piyasa değerinin buradaki sınırların üzerinde olmasıydı, bkz. Altaş ( n 5) 22.

6 Minmo Gahng, Jay R. Ritter and Donghang Zhang, 'SPACs' (SSRN, 2021) <https://ssrn.com/abstract=3775847> Erişim Tarihi 06 Eylül 2021, s. 17.

7 Geri alımların fazla olması sebebiyle birleşmeyi gerçekleştiremeyen birleşme amaçlı ortaklıkların bile yatırımcısına, tasfiye sonucunda yıllık ortalama \%2 oranında getiri sağladığı belirlenmiştir, Gahng, Ritter and Zhang (n 6) 3. 
durulduktan sonra, ikinci kısımda hedef şirketle birleşme sürecinden bahsedilecektir. Bu noktada hedef şirketin belirlenmesi ve bu belirlemede özellikle süre başta olmak üzere hangi etkenlerin rol oynadığı üzerinde durulacaktır. Hedef şirketin belirlenmesinin ardından birleşme amaçlı ortaklığın genel kurulunda bu birleşmenin görüşülmesi ve ortaklık pay sahipleri tarafından oylanması söz konusudur. Bu doğrultuda çalışmanın son kısmında, birleşmenin gerçekleşmemesi veya birleşme gerçekleşecek dahi olsa genel kurulda olumsuz oy kullanıp da ortaklıktan ayrılmak isteyen pay sahiplerine mevzuatta tanınan gönüllü geri alım hakkının nasıl kullanılacağı ve bu sürece ilişkin esasların ayrıntılı bir incelenmesi yapılacaktır.

\section{GENEL OLARAK BİRLEŞME AMAÇLI ORTAKLIK}

\section{A. TANIM}

Birleşme amaçlı ortaklık kavramı Türk sermaye piyasası hukukuna ilk kez mülga 2013 tarihli Ayrılma Hakkı Tebliği ${ }^{8}$ ile girmiştir. Orada verilen tanım, neredeyse kelimesi kelimesine Birleşme Tebliği ${ }^{9}$ m. 4/1-b'de verilen tanımla aynıdır. Bu maddede birleşme amaçlı ortaklık, "Önceden belirlenmiş bir süre ve yatırım stratejisi doğrultusunda, halka arz sonrası oluşacak sermayesini temsil eden payların en az yarısını halka arz etmek ve sonrasında halka açık olmayan bir ortaklık ile birleşme amacı ile kurulan, bu amacı gerçekleştirmek haricinde herhangi bir faaliyeti olmayan, ana sözleşmesinde ve/veya halka açılma nedeniyle düzenlenen izahnamede belirtilen faaliyetler için halka arzdan elde ettiği gelirin azami yüzde onunu kullanarak bakiye kısmın önceden belirlenmiş süre içerisinde hedeflenen birleşme işleminin gerçekleşmemesi halinde kurucular dışındaki ortaklara iade edilmesi amacıyla mevduat, devlet iç borçlanma senedi ve benzeri yatırım araçlarından bir veya birden fazlasına yatırım yapmak suretiyle değerlendirmeyi taahhüt eden ve bu çerçevede gerekli nakit yönetim politikasını halka açılma nedeniyle düzenlenen izahnamede kamuya açıklayan, birleşme işleminin onaylandığ genel kurul toplantısında olumsuz oy kullanan pay sahiplerine ve sona ermesi durumunda kurucular dışındaki tüm pay sahiplerine ait paylara yönelik olarak gönüllü geri alım işlemini izahnamede belirtilen esaslar çerçevesinde gerçekleștirecek olan ve ticaret unvanında birleşme amaçlı ortaklık ibaresi bulunan” şirket olarak tanımlanmaktadir.

Türk hukukundaki bu hukuki kurumun temeli, Amerika Birleşik Devletleri (ABD) hukukunda SPACs olarak adlandırılan modele dayanmaktadır. ${ }^{10}$ SPAC'ler, ABD hukukunda da temel özellikleri bakımından Türk hukukundaki birleşme amaçlı ortaklığa benzer şekilde, kendine ait hiçbir ticari faaliyeti bulunmayan, nakit karşılığı hisselerini halka arz eden; halka arzdan elde ettiği fonun tamamını, halihazırda ticari faaliyeti bulunan bir veya daha fazla şirketle herhangi bir şekilde birleşmesinde (any business combination) veya gelecekte kullanmak üzere bir trust veya escrow

8 Seri: II, No: 23.1 sayılı Önemli Nitelikteki İșlemlere İlişkin Ortak Esaslar ve Ayrılma Hakkı Tebliği, RG 24.12.2013/28861. Bu tebliğ, 27.06.2020 tarihli ve 31168 sayılı Resmi Gazete’de yayımlanan Önemli Nitelikteki İşlemler ve Ayrılma Hakkı Tebliği ile ilga edilmiştir.

9 Seri II, No: 23.2 sayılı Birleşme ve Bölünme Tebliği, RG 28.12.2013/28865.

10 Okutan Nilsson, 'Ortaklık' (n 2) 18 ve 71. 
hesabına aktaran bir şirket olarak tanımlanmıştır. ${ }^{11}$ Her iki hukuki kurum arasındaki farklar, aşağıda yeri geldikçe ele alınacaktır. Ancak bu çalışmada kullanılan birleşme amaçlı ortaklık terimi, yalnızca Türk hukukunda düzenlenen ve sınırları çizilen hukuki kurumu nitelemektedir.

\section{B. BIRLEŞME AMAÇLI ORTAKLIĞIN ÖZELLIKLERI}

Mevzuatta verilen tanımdan yola çıarak, Türk hukukunda düzenlenen birleşme amaçlı ortaklıkların özelliklerini belirlemek mümkündür. Öncelikle birleşme amaçlı ortaklıkların halka arz sırasında herhangi bir ticari faaliyeti bulunmamaktadır. ${ }^{12}$ Bu ortaklıkların kurulma amacı, aktif olarak bir ticari faaliyette bulunan ve işler vaziyetteki halka açı olmayan bir şirketle birleşmektir. Dolayısıyla yatırımcıların neden bu şirkete yatırım yapmak isteyebilecekleri sorusu akıllara gelebilir. Son dönemlerde medyaya da sıkça yansıdığı üzere, birleşme amaçlı ortaklıkların, sponsor olarak da adlandırılan kurucuları, yönetim alanında isim yapmış, ${ }^{13}$ oldukça deneyimli ve başarılı yöneticilerden oluşmaktadır. ${ }^{14}$ Yatırımların şirkete çekilmesinde, şirketin profilinden çok, bu yöneticilerin isimleri önemli bir rol oynamakta; yatırımcı esasen bu kimselerin uzmanlıklarına ve tecrübelerine güvenmektedir. $^{15}$

Halka arz esnasında ticari faaliyeti olmayan birleşme amaçlı ortaklı̆̆ın kuruluştan sonra da hiçbir ticari faaliyette bulunamayacağını söylemek kanaatimizce doğru değildir. ${ }^{16}$ Nitekim birleşme amaçlı

11 Bu tanım (A SPAC is a company with no operations that offers securities for cash and places substantially all the offering proceeds into a trust or escrow account for future use in the acquisition of one or more private operating companies....) için bkz. SEC, Division of Corporate Finance: "Special Purpose Acqusation Companies", CF Disclosure Guidance: Topic No. 11, 22 December 2020, <https://www.sec.gov/corpfin/disclosure-special-purpose-acquisition-companies $>$ Erişim Tarihi 03 Eylül 2021.

12 Dimic, Lawrence and Vulanovic (n 5) 4; Dimitrova (n 1)102; Saengchote (n 1) 1; Okutan Nilsson, 'Ortaklık' (n 2) 1; Neșe Ölekli, 'Halka Açık Anonim Ortaklıklarda Ayrılma Hakkı' (2018) 76(1) İstanbul Hukuk Mecmuası 221, 243; Altaş ( n 5) 20; Melis Aslan, 'Sermaye Piyasası Kanunu’na Göre Şirket Birleşmeleri' (Yüksek Lisans Tezi, Bahçeşehir Üniversitesi 2018), 83.

13 Bir SEC çalışanı, kamuya yaptığı bir açılkamasında, sponsorları 'ünlü (celebrity)' olarak nitelemiştir, bkz. John Coates, 'SPACs, IPOs and Liability Risk under the Securities Law' (SEC Public Statement, 8 April 2021) <https://www.sec.gov/ news/public-statement/spacs-ipos-liability-risk-under-securities-laws> Erişim Tarihi 25 Mayıs 2021.

14 Jenkinson and Sousa (n 5) 5 vd; Okutan Nilsson, 'Structure' (n 5) 254; Altaş ( n 5) 20; Aslan (n 12) 84. Yatırım fonları, Fortune 500'deki eski CEO'lar ve kıdemli yöneticilerin sponsor olduğu SPAC'lerin daha başarılı olduğu da araştırmalarla tespit edilmiştir, Michael Klausner, Michael Ohlrogge and Emily Ruan, 'A Sober Look at SPACs', (European Corporate Governance Institution, Finance Working Paper Series, N. 746/2021) <http://ssrn.com/abstract_id=3720919> Erişim Tarihi 10 Temmuz 2021, s. 4 vd. Sponsorların, ABD hukukunda uygulamada hangi sermaye piyasası aktörlerinden oluştuğuna yönelik ayrıntılı bir çalışma için bkz. Berger (n 1) 68-70.

15 Dimitrova (n 1) 102; Gahng, Ritter and Zhang (n 6) 9 ve 12; birleşme amaçlı ortaklık modelinin dayanağı olan SPAC’e yatırım yapmanın, neredeyse sponsorların itibarı üzerine bahse girmeye denk geldiğine ilişkin bkz. Jackson, AnnaLouise/ Curry, Benjamin: "Special Purpose Acqusition Company: What is a SPAC?", 9 March 2021, Forbes Advisor, https://www.forbes.com/advisor/investing/spac-special-purpose-aquisition-company/>, Erişim Tarihi 20 Mayıs 2021. Türk hukukunda da benzer şekilde bu ortaklıkların, Kotasyon Yönergesi m. 11/1-a uyarınca yalnızca isimleriyle en az 200 milyon TL'lik fonu toplayabilecek sponsorlar tarafından kurulmalarına yönelik kurgunun yapıldığına ilişkin bkz. Derin Altan, Eren Ayanlar, Ece Küreğibüyük ve Şehribar Ünlü, 'Nedir Bu SPAC?' (GKC Partners Sermaye Piyasalar Bülteni, 11 Ocak 2020), <http://www.gkcpartners.com/clients-alerts/Client_Alert_SPAC.pdf> Erişim Tarihi 03 Eylül 2021.

16 Benzer görüş için bkz. Manavgat (n 4) 584. Ancak özellikle halka arzdan elde edilen gelirin \%10’unun, sadece birleşme 
ortaklığın kuruluş amacı belirli bir süre içinde halka açık olmayan bir şirketle birleşmek olsa da, Birleşme Tebliği'ndeki tanıma da uygun olarak izahnamede açıklanmak suretiyle kuruluştan sonra, birleşme için belirlenen süre zarfında ticari faaliyette bulunmasının önünde herhangi bir hukuki engel yoktur. Diğer taraftan her ne kadar teknik olarak 'işletme' konusuna girmese de, birleşme amacı dışında kurulmaya ilişkin herhangi bir hedefi veya amacı olmadığından, birleşme amaçlı ortaklıkların esas sözleşmesinde, işletme konusu olarak bu amacın yer alması yerinde olacaktır. ${ }^{17}$ Bu sebeple birleşme amaçlı ortaklıklar, yatırımcılar için bir nihai yatırım amacı değildir; ancak bu ortaklıklar, yatırımcılara bir yatırım aracı sunmaktadır. ${ }^{18}$

Halka arz edilerek birleşme için gereken fonu toplamayı amaçlayan ve dolayısıyla zorunlu olarak anonim şirket şeklinde kurulan ${ }^{19}$ birleşme amaçlı ortaklığın amacı, belirlenen süre içinde başka bir şirketle birleşmek olduğundan, bu ortaklık, geçici bir ortaklıktır. ${ }^{20} \mathrm{Bu}$ ortaklıkların ticaret unvanlarında birleşme amaçlı ortaklık ibaresinin bulunmasının zorunlu olup olmadığı hususu, doktrinde farklı görüşlerin doğmasına sebep olmuştur. ${ }^{21}$ Bizim de katıldığımız görüşe göre, bu ortaklığın ticaret unvanında 'birleşme amaçlı ortaklık' ibaresinin bulunması gereklidir. Nitekim Birleşme Tebliği’ndeki tanımda açıkça “...ticaret unvanında birleşme amaçlı ortaklık ibaresi bulunan...” ifadesi yer almaktadır ve bu husus kanaatimizce yatırımcıyı koruma amaçlıdır. ${ }^{22}$

Birleşme amaçlı ortaklığın halka arz sonrası oluşacak sermayesini temsil eden payların en az yarısını da halka arz etmesi gerekmektedir. Kotasyon Yönergesi m. 11/1 uyarınca, birleşme amaçlı ortaklığın paylarının kotasyonu şartlarında, "halka arz edilen payların piyasa değerinin en az 200 milyon TL"

amacına hizmet üzere kullanılabileceğine ilişkin doktrinde yer alan karşı görüş için bkz. Okutan Nilsson, 'Ortaklık' (n 2) 80; Altan ve Acar ( n 2) s. 262-263; Aslan ( n 12) 87. Birleşme Tebliği’nde verilen tanımdaki ifadeler doğrultusunda, halka arz gelirlerinin harcanmayarak saklanmasının, ancak hiçbir ticari faaliyette bulunmayan bir şirket tarafından başarılabileceğine ilişkin olarak bkz. Okutan Nilsson, 'Ortaklık' (n 2) 80.

17 Aynı doğrultuda bkz. Okutan Nilsson, 'Ortaklık' (n 2) 88-89. Birleşme amaçlı ortaklığın bu amacının, TTK m. 331/1 uyarınca ekonomik bir amaç veya konu olmadığı; şirketin esas sözleşmesinde TTK m. 339/2-b uyarınca yer alması zorunlu kayıtlardan olan işletme konusu ile ilgisi olmadığı; dolayısıyla bu amacın hukuki anlamının dışında, sadece bir hedef olduğu; sonuç olarak birleşme amaçlı ortaklığın esas sözleşmesinde ekonomik amaç kapsamında giren bir işletme konusunun ayrıca gösterilmesi gerektiği yönündeki karşı görüş için bkz. Manavgat (n 4) 582-583. Ancak bu noktada, bir anonim şirketin birleşme amacıyla kurulduğuna yönelik tespitin nasıl yapılacağı sorunu ortaya çıkmaktadır. Manavgat bu hususta, birleşme amaçlı ortaklık olarak kurulan anonim şirketin bu hedefinin belirlemesinin halka açılma esnasında SPKr tarafından yapılacağını belirtmektedir, Manavgat (n 4) 584.

18 Okutan Nilsson, 'Ortaklık' (n 2) 1.

19 Manavgat (n 4) 582. Bu ortaklık girişim sermayesi fonlarına benzer bir iş modeli içermektedir Okutan Nilsson, 'Structure' (n 5) 254; dolayısıyla aralarında bazı benzerlikler ve farklılıklar mevcuttur, ayrıntılı bir karşılaştırma için bkz. Jenkinson and Sousa (n 5) 2 vd.; Altaş ( n 5) 21; Okutan Nilsson, 'Structure' (n 5) 265.

20 Okutan Nilsson, 'Ortaklık' (n 2) 2 ve 73; Aslan ( n 12) 84.

21 Manavgat, 'tür' niteliğini haiz olmayan bu ortaklıkların, Birleşme ve Bölünme Tebliği hükmüne rağmen, TTK m. 46/1 uyarınca unvanlarında birleşme amaçlı ortaklık ibaresinin yer alamayacağını belirtmektedir, bkz. Manavgat (n 4) 583. Ancak bu çalışmanın hazırlandığı zaman dilimi itibariyle Ticaret Sicili Gazetesi'nde unvanında 'birleşme amaçlı ortaklık' ibaresi bulunan hiçbir şirket kaydı veya BİST’te işlem gören hiçbir birleşme amaçlı ortaklık bulunamamıştır. Dolayısıyla uygulamanın ne yönde gelişeceği henüz belirsizdir.

22 Okutan Nilsson, 'Ortaklık' (n 2) 88; Altan ve Acar ( n 2) s. 263; Aslan ( n 12) 89. Ayrıca yazarlar, tıpkı gayrimenkul yatırım ortaklıkların ticker kodundaki GYO ibaresi gibi, birleşme amaçlı ortaklığın ticaret unvanında bulunması gereken anonim şirket ibaresinin yanında, paylarının BİST kotuna alınırken bu şirketlerin ticker kodunda BAO şeklinde özel bir sembol dizilimi olmasına dair öneride bulunmaktadır, bkz. Altan ve Acar ( n 2) s. 263; aynı yönde bkz. Altaş ( n 5) 20. 
olmasının yanı sıra "halka arz edilen paylarının halka arz sonrası oluşacak ödenmiş ya da çıkarılmış sermayesine oranının en az \%50 olması" şartı aranmaktadır. Aynı şart, Birleşme ve Bölünme Tebliğinde yalnızca "halka arz edilen paylarının halka arz sonrası oluşacak sermayesini temsil eden payların en az yarısını halka arz etmek" şeklinde ifade edilmiş olsa da bu ifade farklılı̆̆ının pratik bir sonucu bulunmamaktadır. ${ }^{23}$ Kotasyon Yönergesi’nde, halka arz edilen payların ayrıca en az \% 80 'inin kurumsal yatırımcıya ${ }^{24}$ satılmış olması şartı, yatırımın riskli olduğunun bir göstergesidir. ${ }^{25}$ Birleşme amaçlı ortaklığın, 6362 sayılı Sermaye Piyasası Kanunu (SPKn) m. 7 uyarınca halka arz esnasında hazırlamakla yükümlü olduğu izahnamede, belirli bazı bilgileri kamuya açıklaması zorunludur. $\mathrm{Bu}$ kapsamda birleşme amaçlı ortaklık, Birleşme Tebliğinndeki tanım uyarınca, yatırım yapacağı ve gelir getirme potansiyeline sahip halka açı olmayan bir hedef şirketle hangi süre içinde birleşeceğini izahnamesinde göstermek zorundadır.

Birleşme amaçlı ortaklığın, halka arzdan sonraki malvarlığı, halka arzdan elde ettiği nakit fonlardır ve bu fonların kullanım amacı, alanı ve oranı mevzuatta belirlenmiştir. Başlangıçta hiçbir ticari faaliyeti olmayan birleşme amaçlı ortaklıklar, halka arzdan elde ettikleri gelirle birleşme amacını gerçekleştirmek için gereken kaynağı elde etmiş olurlar. Dolayısıyla ortaklık, kuruluş amacına uygun bir şekilde, öngörülen sürede birleşme gerçekleştirebilmek için, bu gelirin en az \%90'inı belirli yatırım araçlarında değerlendirmek üzere ayırmak ve kalan \%10’nunu da ortaklığın işletilmesi ve eğer izahnamedeki yatırım stratejisinde öngörülmüşse ticari faaliyette bulunabilmesi için gereken giderlere ayırmak durumundadır. ${ }^{26}$ Birleşme amaçlı ortaklık, söz konusu fonun \%90'lk kısmını, izahnamesinde açıklayacağ ${ }^{27}$ bir nakit yönetim politikası çerçevesinde mevduat, devlet iç borçlanma senedi gibi yatırım araçlarında nemalandırabilir. Nihai olarak bu fonun kullanım amacı ise birleşme işlemi olmalıdır, birleşmenin gerçekleşmemesi durumunda da bu fon gönüllü geri alım için kullanılmak zorundadır. ${ }^{28}$

Halka arzdan elde edilen gelirin tam olarak nerede tutulacağı konusunda mevzuatta açık bir hüküm bulunmamaktadır. Uygulamada başvurulan yöntemlerden olan escrow veya trust sözleşmesinin

23 Okutan Nilsson, 'Ortaklık' (n 2) 75-76. Birleşme ve Bölünme Tebliği metninden anlaşıldığı üzere halka arz, sermaye artırımı yoluyla yapılacak olup (Manavgat (n 4) 582) SPKn m. 12/1 uyarınca gerek halka arzda gerek sonraki sermaye artırımlarında pay bedellerinin tam ve nakden ödenmesi gerekmektedir. Sonuç olarak halka açık şirket açısından çıkarılmış sermaye, ödenmiş sermayeye eşit olacaktır.

24 Kurumsal yatırımc1, 28.06.2013 tarihli ve 28691 sayllı Resmi Gazetede yayımlanan Seri II, No: 5.2 sayll Sermaye Piyasası Araçlarının Satışı Tebliği m. 4/1-j’de "Kurulun yatırım kuruluşlarına ilişkin düzenlemelerinde tanımlanan ve talebe dayalı olarak profesyonel kabul edilenler dişındaki profesyonel müssterileri” ifade edecek şekilde tanımlanmıştır. Profesyonel müşteri tanımı da 17.12.2013 tarihli ve 28854 sayılı Resmi Gazetede yayımlanan Seri III, No: 39.1 sayılı Yatırım Kuruluşlarının Kuruluş ve Faaliyet Esasları Hakkında Tebliğ m. 31'de verilmiştir.

25 Coates (n 13); Okutan Nilsson, 'Structure' (n 5) 254; dolayısılla alınan diğer bazı önlemlerin yanı sıra, bu düzenleme ile bireysel yatıımcının korunması amaçlanmıştır, bkz. Altan, Ayanlar, Küreğibüyük ve Ünlü (n 15) 3. Diğer taraftan yatırımcılar açısından bu yatırımın riskten uzak olduğuna ve bu sebeple ABD piyasalarında bu kadar popüler olduğuna yönelik olarak bkz. Jenkinson and Sousa (n 5) 20.

26 Manavgat (n 4) 585.

27 Birleşme amaçlı ortaklıkların paylarını halka arz ettiği sırada hazırlayacağı izahnamesinde yer verdiği bu bilgilerin yanlış, yanıltıcı veya eksik olması durumunda somut olay bazında SPKn m. 10 ve SPKn m. 32 uyarınca sorumluluğun doğması kaçınılmazdır.

28 ABD hukukundaki benzer kullanım amaçları için bkz. Klausner, Ohlrogge and Ruan (n 14) 7. 
yapılması veya bankacılık sektöründe kullanılan bloke hesapların açılması suretiyle bir emanet hesapta halka arz gelirlerinin muhafaza edilmesi ve bu hesabın, salt birleşme veya gönüllü geri alım işlemlerinde kullanılma amacına vakfedilmesi uygun olacaktır. ${ }^{29}$ Bu gibi mekanizmalardan dolayı, birleşme amaçlı ortaklık modeli, ayrılma hakkının güvenceye alınması ve gönüllü geri alım programı sebebiyle oldukça avantajlıdır. ${ }^{30}$

\section{HEDEF ŞiRKET ILE BIRLEŞME SÜRECi}

\section{A. HEDEF ŞIRKETIN BELIRLENMESi}

\section{BIRLEŞME IÇIN HALKA AÇIK OLMAYAN ŞIRKET ARAYIŞI}

Birleşme amaçlı ortaklığın, paylarını halka arz ederken hazırlayacağı izahnamesinde, bir yatırım stratejisi oluşturması gerekmektedir. Burada bahsedilen yatırım stratejisi, esasen hedef şirkete yapılması beklenen yatırıma, diğer bir deyişle hedef şirketin seçiminde ve onunla birleşmede esas alınacak kriterlere ilişkindir. ${ }^{31}$ Nitekim birleşme amaçlı ortaklığın paylarının halka arzında, hedef şirkete ilişkin bir belirlemenin yapılmamış olduğu izahnamede belirtilmeli ve hatta bu yönde hiçbir görüşmenin yapılmaması gerekmektedir. ${ }^{32}$ İzahnamede ayrıca hedef şirkete ilişkin, sağlık, eğitim, gıda gibi bir veya birden fazla sektörün belirlenmesi de söz konusu olabilmektedir. ${ }^{33}$ Nitekim hedef şirkete ilişkin yapılan sektörel veya ülkesel belirlemeler sonucunda birleşme işleminin başarıya ulaştığı yapılan çalışmalarla kanıtlanmıştır. ${ }^{34}$ Birleşme amaçlı ortaklığın birleşmesi gereken hedef şirketin, halka açık olmayan, operasyonel, gelecek vadeden bir şirket olması gerekmektedir. ${ }^{35}$

29 Birleşme amaçlı ortaklıkların dayanak modeli olan SPAC’ler için bu durumda, halka arzdan elde edilen gelirin \%80'inden fazlasının, en geç 24 ay içinde tamamlanacak olan birleşmeye kaynak sağlamak amacıyla saygın kredi kuruluşları nezdinde tutulan bir escrow veya trust hesabında saklanması gerekmektedir, bkz. Anand ( n 1) 21; Dimitrova (n 1) 102; Okutan Nilsson, 'Ortaklık' (n 2) 86; Altaş ( n 5) 21. Özellikle SEC tarafından Açık Çek Şirketler için bu yönde düzenlenmiş Rule 419 kapsamında olmasa da SPAC’ler de bu uygulamaya tabidirler. Mevzuat için bkz. $17 \mathrm{CFR}$ $\$ 230.419(\mathrm{~b})(3)$ - Offerings by Blank Check Companies.

30 Okutan Nilsson, 'Structure' (n 5) 268.

31 Okutan Nilsson, 'Ortaklık' (n 2) 74-75.

32 ABD hukukundaki benzer kural için bkz. Jenkinson and Sousa (n 5) 5; Berger (n 1) 70; Saengchote (n 1) 1; Gahng, Ritter and Zhang (n 6) 2. Aksi halde bu hedef şirketin veya birleşme görüşmelerine başlandığının izahnamede açıklanması gerekecektir. Ancak tam tersi durum, benzer bir düzenlemenin olmamasından dolayı Avrupadaki SPAC’ler için söz konusudur ve bu SPAC’lerin çok hızlı bir şekilde birleşmeyi tamamladıkları gözlemlenmiştir, bkz. Ignatyeva, Rauch and Wahrenburg (n 1) 71.

33 Aynı doğrultuda bkz. Manavgat (n 4) 584.

34 Avrupada SPAC'lerin ülkesel olarak tercihlerinde belirgin bir ülke yer almazken, hedef şirketin belirlenmesinde rol oynayan esas faktörlerin hedef şirketin bulunduğu ülke borsaların düzenlenmeleri ile vergiye ilişkin hususlar olduğu belirlenmiştir, Ignatyeva, Rauch and Wahrenburg (n 1) 65 ve 67. Bunun yanı sıra, SPAC’lerin birleşme sonrası ticari hayatta kalma şanslarının da bu şekilde arttığına yönelik olarak bkz. Vulanovic (n 1) 690.

35 Berger (n 1) 68; Altan ve Acar (n 2) s. 256; SPAC'lerin aslında kendine yetebilen ve finansal durumu itibariyle sermaye piyasasına kendi başına da erişebilme kapasitesine sahip şirketlere yöneldiğine ilişkin bkz. Ignatyeva, Rauch and Wahrenburg (n 1) 72. Doktrindeki karşı görüş olarak, sermaye piyasasına kendi başına geleneksel halka arzla erişme imkânı bulan şirketlerin, SPAC'in hedef şirketi olmak suretiyle halka açılmayı tercih etmediğine ilişkin olarak da bkz. Johannes Kolb and Tereza Tykvová, 'Going Public via Special Purpose Acquisiation Companies: Frogs do not Turn into Princes' (2016) 40 Journal of Corporate Finance 80, 91. 
Nitekim, bir birleşme amaçlı ortaklığın ticari geleceği, birleşme sonrası için hedef şirketin finansal performansı ile yakından ilgilidir. ${ }^{36}$

Şüphesiz burada birleşmelerin, halka açılma prosedürüne nazaran daha az hazırlık gerektirmesi, halka açılmada karşılaşılan piyasa riskini daha az taşıması ${ }^{37}$ ve şartların gerçekleşmesi halinde kolaylaştırılmış birleşmeden dahi yararlanabilme olanağı, hedef şirketler açısından bu yöntemle birleşmeyi çekici kılabilir. ${ }^{38}$ Geleneksel bir ilk halka arzda, şirketin paylarının piyasada, satış yöntemine göre hangi fiyattan ve ne miktarda satılacağı her zaman belli olmayabilir veya halka arz başarıya ulaşmayabilir. Ancak birleşme amaçlı ortaklıkla birleşmek suretiyle halka açılmak, bu risklerin hiçbirini taşımaz, bu yöntemin hedef şirket için getirileri oldukça nettir: piyasa riskine veya ağır halka arz prosedürüne maruz kalmadan halka açılmak, sonunda çok iyi bir yönetim ekibi ile çalışmak, saygın bir yatırımcı profiline ${ }^{39}$ ve ciddi miktarda hazır bir fona sahip olmak. ${ }^{40}$ Halka açı olmayan bir şirketin, sermaye piyasası düzenlemelerini dolanarak geleneksel yoldan değil de halka açık bir şirketi kullanarak halka açılmasını önleyici düzenlemeler, Birleşme Tebliği m. 12/4, 5, 6'da öngörülmüştür; ancak bu hükümlerin birleşme amaçlı ortaklıklara uygulanmayacağı aynı maddenin 8. fikrasında açıkça belirtilmiştir. Yine de birleşme amaçlı ortaklıklar açısından aşağıda ayrıntılı olarak açılanan gönüllü geri alım işlemi gibi başka koruyucu mekanizmalar öngörülmüștür.

ABD hukukunda ise SPAC’ler aracilığıyla halka açılma yöntemini daha çekici kılan bir başka özellik daha bulunmaktadır. Geleneksel halka arzdan ziyade bu yöntemin seçilmesine sebep olan hususlardan biri, SPAC’lerin geleceğe yönelik tahminleri için ilgili kanunun, bir sorumsuzluk hükmü öngörmesidir. ${ }^{41}$ Geleneksel halka arzları kapsamayan ilgili hükme göre, halka açık şirket statüsünde olan SPAC'ler, vekalet bildirimlerinde (proxy statements), yıllık raporlarında ve SEC nezdinde yapilan herhangi bir bildirimde geleceğe yönelik tahminlerini, uygun bir dille ifade edebilir. Daha sonra tahmin edilenden farklı bir durumun gerçekleşmesi halinde ise yöneticilerin geçmişte bulundukları tahminden ötürü sorumlu tutulamayacakları (safe harbour provision) kabul edilmiştir. ${ }^{42}$ Söz konusu hükme göre, birleşmenin gerçekleşmemesi halinde, bundan zarar gördüğünü ileri süren davacının, yöneticilerin bilerek yanlış açıklamalarda bulunduğunu kanıtlaması gerekir. ${ }^{43}$ Dolayısıyla yukarıda

36 Klausner, Ohlrogge and Ruan (n 14) 46; Ignatyeva, Rauch and Wahrenburg (n 1) 65. Ayrıca birleşmeden sonraki iki yıl boyunca da hedef şirketlerin olumsuz bir gelişim gösterdiği kanıtlanmıştır, bkz. Ignatyeva, Rauch and Wahrenburg (n 1) 72.

37 Gahng, Ritter and Zhang (n 6) 13; Kolb and Tykvová (n 35) 81; Dimitrova (n 1) 103; Altan ve Acar (n 2) s. 256.

38 Özellikle yabancı şirketlerin SPAC’ler aracılığıyla ABD'deki borsalara erişiminin kolaylaşması, bu yöntemi halka açılmadan çok daha çekici hale getirdiğine yönelik bkz. Vulanovic (n 1) 690.

39 Söz konusu yatırımcı profiline ilişkin kriterler için bkz. BİsT Kotasyon Yönergesi m. 11/1-b.

40 Kolb and Tykvová (n 35) 81; Berger (n 1) 68 ve 71-72; Vulanovic (n 1) 680; Dimitrova (n 1) 103; Okutan Nilsson, 'Structure' (n 5) 255. Diğer taraftan ABD hukukunda Ocak 2019 ve Haziran 2020 ylllarını kapsayacak şekilde 47 SPAC üzerinde yapılan araştırma sonucunda, bir SPAC ile birleşerek halka açık şirket olmanın, geleneksel halka açılmaya kıyasla daha maliyetli olduğu da araştırmalarla tespit edilmiştir; ayrıntılı bilgi için bkz. Gahng, Ritter and Zhang (n 6) 7-8.

41 Bkz. The Private Securities Litigation Reform Act (PSLRA), 15 U.S.C. $\$ \$ 77 z-2,78 u-5$.

42 Klausner, Ohlrogge and Ruan (n 14) 42-43; Gahng, Ritter and Zhang (n 6) 5.

43 Gahng, Ritter and Zhang (n 6) 13. 
sayılan avantajların yanı sıra, birleşme amaçlı ortaklık ile birleşme, geleneksel halka arza nazaran daha tercih edilebilir bir yöntem haline gelmiştir.

\section{BIRLEŞMEDE SÜREYE ILIŞKIN HUSUSLAR}

SPAC uygulamasından farklı olarak, ${ }^{44}$ Türk hukukunda birleşme amaçlı ortaklığın, birleşmede süreye ilişkin bir üst sınır mevzuatta öngörülmemiştir. Bu konuya ilişkin tek düzenleme, BİST Kotasyon Yönergesi m. 24'te, ${ }^{45}$ azami 24 ay sonunda veya izahnamede gösterilen süre sonunda hedef şirketle birleşememişse, birleşme amaçlı ortaklıkların paylarının kottan çıkarılacağı şeklindedir. İzahnamede belirlenebilecek sürenin 24 aydan daha uzun olabileceği madde metninden anlaşıldı̆̆ından, birleşme için bir üst sınırın olmadığı ve sürenin serbest bir şekilde belirlenebileceği kabul edilmelidir. ${ }^{46}$

Birleşilecek hedef şirketin belirlenmesinde dikkat edilmesi gereken en önemli hususlardan biri süredir. Birleşme ve hedef şirketin belirlenmesi için belirlenecek sürenin uzun tutulması, pay sahipleri nezdinde olumsuz bir kanının oluşmasına yol açabilir. ${ }^{47}$ Normal şartlarda, halka arzdan hemen sonra fon toplayan birleşme amaçlı ortaklık, hedef şirket arayışlarına başlamaktadır. ${ }^{48}$ Dolayısıyla hedef şirkete ve birleşmeye ilişkin duyurunun erken yapılmasının SPAC’lerin başarı şansı üzerinde olumlu bir etkisinin olduğu söylemek yanlış olmayacaktır. ${ }^{49}$ İzahnamede belirlenen yatırım süresinin sonuna gelinmesine rağmen birleşmenin henüz gerçekleşmemesi sonucunda oluşacak süre baskısı, kurucuların menfaatiyle pay sahiplerinin menfaatinin çatışmasına (agency conflict) yol açabilir. ${ }^{50}$

44 NASDAQ Kotasyon Kurallarına göre, SPAC’lerin birleşmesi için öngörülen süre sınırı en fazla 36 aydır. Daha kısa süreler, şirketlerin izahnamelerinde belirtilebilir. Ayrıntılı bilgi için bkz. NASDAQ Listing Rules, IM-5101-2: "Listing of Companies Whose Business Plan is to Complete One or More Acquisitions", <https://listingcenter.nasdaq.com/ rulebook/nasdaq/rules/Nasdaq\%205100\%20Series> Erişim Tarihi 24 Mayıs 2021. Ayrıca uygulamada SPAC’lerin, 18 ila 36 ay arasında, en fazla 24 ay içinde birleşmeyi tamamladıkları görülmüştür, Dimitrova (n 1) 102; Saengchote (n 1) 1; Kolb and Tykvová (n 35) 84; Okutan Nilsson, 'Structure' (n 5) 254; Altan ve Acar ( n 2) s. 253; Altaş ( n 5) 21; bu hususta ayrica bkz. SEC's Investor Bulletin, 10 December 2020, "What You Need to Know About SPACs - Period to consummate the initial business combination" <https://www.sec.gov/oiea/investor-alerts-and-bulletins/what-you-need-know-aboutspacs-investor-bulletin>, Erişim Tarihi 24 Nisan 2021.

45 BİST A.Ş., 2015 tarihli Kotasyon Yönergesi, <https://www.borsaistanbul.com/files/borsa-istanbul-kotasyon-yonergesi. pdf $>$, Erişim Tarihi 23 Mayıs 2021.

46 Okutan Nilsson, 'Ortaklık' (n 2) 74.

47 Dimitrova (n 1) 114; Okutan Nilsson, 'Ortaklık' (n 2) 60. ABD’de 2018 Ocak ile 2020 Aralık ayları arasındaki SPAC’ler üzerinde yapılan bir araştırmaya göre, hedef şirketin ve birleşmenin medyada duyurulması süresi, 2018 yılında 715 günden, 2020 yılının sonuna kadar 79 güne düşmüştür, bkz. Saengchote (n 1) 6 .

48 Dimitrova (n 1) 102; bu arayışın ne kadar ciddi olabileceğine yönelik olarak "birleşme avı (acquisition hunt)" ifadesi kullanılmıştır, bkz. Berger (n 1) 70. Ayrıca ABD hukukundaki birleşmelerde hedef şirketin belirlenmesinde, SPAC’lerin 100'den fazla şirketi inceledikleri ve çok karmaşı sözleşmelerle birleşmeyi gerçekleştirdiklerine yönelik vaka incelemeleri (case studies) için bkz. Berger (n 1) 71-74. Bu arayışta bazı SPAC’lerin ayrıca başka bir kuruma para ödemek suretiyle hedef şirketi bulma işini profesyonel olarak yaptırdıkları, ancak bu durumun, kendi yetersizliklerine işaret etmesi ve ilgili kuruma ödenecek paranın escrow hesapta tutulan miktardan karşılanması sebebiyle negatif bir etkisi olduğu belirtilmiştir, bkz. Vulanovic (n 1) 692.

49 Dimitrova (n 1) 112. Nitekim birleşmeden sonraki ticari hayatında başarısız olduğu tespit edilen SPAC’lerin birleşme duyurusunu, başarılı olanlara nazaran daha geç yaptıkları (bkz. Jenkinson and Sousa (n 5) 12-13) ve hedef şirketin belirlenmesi duyurusunu yapan SPAC’lerin yıllık ortalama \%1,9 gelir artışı yaşadıkları (Ignatyeva, Rauch and Wahrenburg (n 1) 73) tespit edilmiştir.

Okutan Nilsson, 'Ortaklık' (n 2) 59. 
Hedef şirket belirlendikten sonra kamuya yapılan açıklama ve genel kurul toplantısı tarihleri arasındaki sürenin uzaması halinde, özellikle istikrarsız piyasalarda birleşmenin onaylanmaması riski artabilir. ${ }^{51}$ Belirlenen yatırım süresinin azalması, gerek kurucu payları gerek varantlarla büyük ölçüde finansal olarak şirketin başarısına bağlanan yöneticileri birleşmeyi ne pahasına olursa olsun gerçekleştirmeye iteceği için, birleşme amaçlı ortakllğı uzun dönemde çok büyük fayda sağlamayan bir hedef şirketle birleşmeye itebilir. ${ }^{52}$

\section{B. BIRLEŞMENIN GERÇEKLEŞMESI VE ÖZEL DÜZENLEMELER}

\section{BIRLEŞME YÖNTEMININ BELIRLENMESi}

Birleşme amaçlı ortaklıkların, hedef şirketle hangi yöntemle birleşecekleri konusunda mevzuatta herhangi bir sınırlama öngörülmemiştir. ${ }^{53} \mathrm{ABD}$ uygulamasında bu yöntem oldukça geniş tutularak herhangi bir ticari kombinasyon yeterli görülmüşken ${ }^{54}$ Avrupa'da SPAC’ler, küçük çaplı birden fazla birleşme gerçekleştirmektedir. ${ }^{55}$ Türk hukukunda ise, benzeri bir yaklaşımın benimsenmediği, Birleşme Tebliği’ndeki kullanımın, 6102 sayılı Türk Ticaret Kanunu (TTK) m. 136 vd. hükümlerinde düzenlendiği şekliyle teknik bir birleşmeye işaret ettiği kabul edilmektedir. ${ }^{56}$ Nitekim birleşilecek şirketin de halka açık olmayan bir şirket olma zorunluluğu ve bu ortaklıkların kabulünde model alınan SPAC'lerin, Türk hukuk mevzuatına 'özel amaçl devralma şirketleri' yerine 'birleşme amaçlı ortaklık' şeklinde alınması, hedef şirketle birleşme yönteminin belirlenmesinde, özellikle teknik anlamda birleşmenin tercih edildiği görüşünü desteklemektedir. Türk sermaye piyasasında halka açılma oranlarının diğer ülkelere göre oldukça düşük olması, birleşme amaçlı ortaklıkla halka açılmayı teşvik etmek için bu tercih açısından haklı bir gerekçe oluşturmaktadır.

Birleşme amaçlı ortaklığın hedef şirketle birleşmesi gerek yeni kuruluş şeklinde gerekse de devralma şeklinde birleşme olmak üzere iki yöntemle gerçekleşebilir. Bu kapsamda, ortaklığın, devralan veya devrolan şirket olması arasında mevzuatta bir ayrım yapılmamıştır. Birleşme amaçlı ortaklığın, birleşmede devrolan şirket olması durumunda devralan şirketin, hem birleşmeden önceki sermayesini temsil eden hem de ihraç edeceği yeni paylar için ihraç belgesi hazırlaması Birleşme Tebliği m.

51 Berger (n 1) 74; Kolb and Tykvová (n 35) 84; yine de istikrarsız piyasalardaki hedef şirketlerin, geleneksel halka açılmadansa, bir SPAC ile halka açılmayı tercih ettiklerine yönelik olarak bkz. Kolb and Tykvová (n 35) 88.

52 Klausner, Ohlrogge and Ruan (n 14) 20; Dimitrova (n 1) 99; Gahng, Ritter and Zhang (n 6) 1; Paul\&Weiss, Client Memorandum, 17 March 2021, "What SPAC Sponsors, Directors and Officers Can Do to Mitigate Their Litigation Exposure" <https://www.paulweiss.com/practices/litigation/securities-litigation/publications/what-spac-sponsorsdirectors-and-officers-can-do-to-mitigate-their-litigation-exposure?id=39540> Erişim Tarihi 26.06.2021, s. 2-3; hatta en çok bu hususta davaların açıldığına yönelik bkz. s. 7; Okutan Nilsson, 'Structure' (n 5) 264.

53 Manavgat (n 4) 582.

54 Jenkinson and Sousa (n 5) 6; bu noktada, birleşme, karşılıklı iştirak, bir malvarlığının alınması, hisse alım-satımı, yeniden organizasyon, bir veya birden fazla operasyonel işletme veya malvarlığı ile benzeri bir ticari kombinasyon kabul edilmektedir, bkz. NYSE Listing Standards, Section 1, 102.06 - Minimum Numerical Standards - Acquisition Companies: "... a business combination in the form of a merger, capital stock exchange, asset acquisition, stock purchase, reorganization, or similar business combination with one or more operating businesses or assets".

55 Ignatyeva, Rauch and Wahrenburg (n 1) 65.

56 Okutan Nilsson, 'Structure' (n 5) 255-256; Aslan ( n 12) 86. Bizim de katıldığımız görüşünde yazar, bu tercihin sebebinin, şirketleri halka açılmaya teşvik edilmek istenmesi olabileceğini belirtmektedir, bkz. Okutan Nilsson, 'Ortaklık' (n 2) 79. 
20/2-a uyarınca zorunludur. Bu haliyle halka açık olmasa dahi devralan şirket konumundaki hedef şirketin, sermayesine ilişkin gerekli kamuyu aydınlatmayı yapması ve paylarının SPKn kapsamına alınması sağlanmaktadır. Ancak birleşmeden sonra oluşan şirketin paylarının doğrudan borsaya kote olmasının önüne geçilmiştir ${ }^{57}$ ve Kotasyon Yönergesi m. 40/3 uyarınca birleşme sonrası şirketin SPKn kapsamından çıkma şartlarını sağlamaması gerektiği belirtilmiştir.

Birleşme amaçlı ortaklıkların hedef şirketle birleşmesine ilişkin, Birleşme Tebliği m. 12/4 ve 5 hükümleri de uygulama alanı bulmaz. Bu haliyle birleşme amaçlı ortaklıklar, gerek kendi sermayesini \%100 arttırarak kendinden en az iki kat daha büyük bir şirketle devralma şeklinde birleşebileceği gibi, yeni kuruluş şeklinde birleşmede bu ortaklıkların kendi pay sahiplerinin yeni şirkette azınlık olmasına yol açacak birleşmelere de katılması mümkündür.

\section{BIRLEŞMENIN GENEL KURUL ONAYINA SUNULMASI}

\section{A. BIRLEŞME HAZIRLIKLARI}

Hedef şirket belirlendikten sonra bu durum, Sermaye Piyasası Kurulu’nun (SPKr) özel durum açıklamalarına ilişkin düzenlemeleri doğrultusunda kamuya açıklanmalıdır. ${ }^{58}$ Yapılan kamuyu aydınlatmadan sonra, kural olarak birleşme amaçlı ortaklığın genel kurulunda birleşmenin onaylanması gereklidir. ${ }^{59}$ Bunun için, taraf şirketlerin yönetim organlarının aldıkları kararın kamuya açıklanmasının ardından, finansal tabloların bağımsız denetimden geçirilmesi ve birleşmede değişim oranlarının tespiti açısından bir uzman kuruluş raporunun alınması gerekir. Ayrıca pay sahiplerinin bilgilendirilmesine yönelik bir birleşme raporunun hazırlanması ile gerekirse esas sözleşme değişikliklerine ilişkin bir taslağın hazırlanması söz konusu olacaktır. Birleşme Tebliği m. 5 uyarınca pay sahiplerine yönelik hazırlanacak duyuru metninin de SPKr tarafından onaylanması ve kamuya açıklanması gerekir. Genel kurul toplantı tarihinden en az otuz gün önce, Birleşme Tebliği m. 8/2'de öngörülen birleşme belgeleri pay sahiplerinin incelemesine açılacaktır. ${ }^{60}$

Birleşme amaçlı ortaklık yönetim kurulu ile hedef şirketin yönetim kurulu, birleşme görüşmeleri sırasında due diligence incelemesi yapmaları ve birleşme hususunda prensipte anlaşmaları halinde de niyet mektubu (letter of intent) vermeleri gerekecektir. ${ }^{61} \mathrm{Bu}$ aşamada birleşmeye yönelik hedef

57 Okutan Nilsson, 'Ortaklık' (n 2) 182.

58 Avrupa’daki SPAC’ler açısından yoğun bir düzenleme olmadığı için uygulamada bu noktada prosedürel farklılıklar da göze çarpmaktadır. Yapılan bir araştırmaya göre, bazı SPAC’lerin pay sahiplerinin birleşme hakkında oy kullanmasına izin verilmemişken bazı SPAC’ler ise birleşmeyi veya hedef şirketi kamuya açıklamamıştır, ayrıntılı bilgi için bkz. Ignatyeva, Rauch and Wahrenburg (n 1) 71.

59 Birleşmeye ilişkin prosedür ve TTK m. 136 vd. düzenlemeleri doğrultusunda ayrıntılı bir çalışma için bkz. Okutan Nilsson, 'Ortaklık' (n 2) 167-188.

60 ABD hukukunda, yapılan bir araştırmaya göre, SPAC’lerin ortalama 362 gün önceden satın alma duyurusu yaptıkları ve bu duyurudan sonraki 300 güne kadar birleşme işlemini tamamladıkları tespit edilmiştir, bkz. Jenkinson and Sousa (n 5) 12-13. Birleşme duyurusundan sonraki ortalama 204 güne kadar işlemin tamamlandığına ilişkin çalışma için ayrıca bkz. Vulanovic (n 1) $686 \mathrm{vd}$.

61 Niyet mektubu, birleşme sonucunda ortaya çıkacak yapıya ilişkin bilgilerin ana hatlarıyla ortaya koyulduğu ve due diligence yapıldıktan sonra aradaki görüşmelerin resmiyet kazandığı aşamada yazılı bir belgedir ve hukuken bu mektup icaba davet olarak nitelendirilir, bkz. Hüsnü Turanl, Yeni Türk Ticaret Kanunu’na Göre Ticaret Şirketlerinin Birleşmesi 
şirketin ödemesi gereken aracılık ücreti doğrudan gider olarak karşımıza çıkmakta iken, aynı zamanda birleşmede ödenmesi gereken ve aşağıda ayrıntıları incelenen dolaylı bir gider kalemi olarak payların sulanması ${ }^{62}$ söz konusudur.

Niyet mektubu veya ön anlaşma gibi herhangi bir belgenin kamuya açıklanmasından karar gününe kadar geçen süre içinde, birleşme amaçlı ortaklığın paylarının piyasa fiyatındaki değişiklikler, yatırımcının birleşmeye yönelik değerlendirmesi hakkında fikir edinilmesini sağlar. ${ }^{63}$ Ancak pay fiyatları, birleşme kararından memnun kalınmaması da dahil her halde, payı satıp çıkma imkanından dolayı emanet hesapta tutulan pay başı miktarın altına düşmemelidir; aksi halde piyasanın birleşmeye olumsuz baktığı sonucu çıkabilir. Aynı zamanda, ABD hukukunda genel kurul toplantısından önce SPAC'in paylarının bloklar halinde satın alınması ya da kurucuların hedef şirketteki yatırımcılar veya başka ilgililer aracılığıyla kurumsal yatırımcılardan olumlu oyu satın almaya çalışması da birleşmenin SPAC açısından artı bir değer getirmediği ve dolayısıyla birleşmeden sonra SPAC’in başarısız olacağı yorumunu yansıtabilir. ${ }^{64}$ Nitekim öğretide bu durumdaki şirketler, kötü SPAC’ler (bad SPACs) olarak adlandırılmıştır. ${ }^{65}$

Birleşme amaçlı ortaklığın kurucuları, bu iş için herhangi bir ücret almayıp tamamen halka arzdan önce nominal değerden edindikleri \%20'lik paylarının, ortaklı̆̆ın hisselerinin özellikle birleşme sonrasında değerleneceği beklentisiyle çalışmaktadırlar. ${ }^{66}$ Dolayısıyla yöneticiler, birleşme amaçlı ortaklığın bu birleşmeyi tamamlayarak başarıya ulaşmasını istemekte ve bu noktada yöneticilerle pay sahiplerinin menfaatleri örtüşmektedir. Bu husus, TTK m. 393’te düzenlenen yönetim kurulu toplantılarında müzakereye katılma yasağının burada da uygulanıp uygulanmayacağını akla getirebilecektir. Birleşme amaçlı ortaklığın menfaati ile bu ortaklığa ciddi anlamda finansal geleceği bağlı olan yöneticilerin, izahnamede belirlenen yatırım süresinin sonuna yaklaşılmasıyla menfaatlerinin çatışması haline özel olarak TTK m. 393 hükmünün uygulanabilirliğinin tartışılması gerekir. Nitekim burada kanun metninde bahsedilen şirket ve yönetici arasındaki menfaat çatışması,

(Orion, 2014), $102-104$.

62 Bkz. aşa. "Paylarda Sulanma Etkisi” başlığı altındaki açıklamalar.

63 Jenkinson and Sousa (n 5) 8-9. Piyasadaki tepkiler, bunun da ötesinde şirketin geleceğinin nasıl olacağına dair bir tür gösterge niteliği taşımaktadır ve yatırımcılar genel kurulda oylarını kullanmadan önce birleşme duyurusunun ardından piyasadaki fiyatların tepkisini gözlemlemelidir, Jenkinson and Sousa (n 5) 21.

64 Berger (n 1) 74-75; Jenkinson and Sousa (n 5) 16; Klausner, Ohlrogge and Ruan (n 14) s. 16; Dimitrova (n 1) 113 vd. Kurucuların gelirlerinin \%34'ünü diğer yatıımcıların geri alım yapmaması veya daha fazla yatıım yapması amacıyla kullandığı tespit edilmiştir, Gahng, Ritter and Zhang (n 6) 5. Diğer taraftan, hedef şirketteki pay sahiplerinin SPAC hisselerini satın alması da aynı sonuca ulaşılmasını sağlayacaktır, ancak her ne şekilde olursa olsun SEC bilgileri kapsamında, söz konusu yöntemlere, genel kurul karar toplantılarından önce başvurulmaktadır, Jenkinson and Sousa (n 5) $16-17$.

65 Bkz. Jenkinson and Sousa (n 5) 9, 12 ve 21; Dimitrova (n 1) 108.

66 Jenkinson and Sousa (n 5) 6; Klausner, Ohlrogge and Ruan (n 14) 20; Kolb and Tykvová (n 35) 83-84; Dimitrova (n 1) 102; Gahng, Ritter and Zhang (n 6) 1; Okutan Nilsson, 'Structure' (n 5) 255 ve 263. Diğer taraftan birleşme amaçlı ortaklığın, halka arz esnasında ihraç ettiği ortaklık varantlarından (warrants) da satın alarak ortaklığın başarısına ciddi ölçüde finansal açıdan bağlanmaktadırlar. Yapılan çalışmalar, halka arz esnasında sponsorların daha fazla varant satın almasının, onların ortaklığa daha çok bağlandığı, güvendiği anlamına geldiğinden birleşmenin başarısına olumlu etkisi olduğu göstermiştir, Vulanovic (n 1) 695. 
özellikle yatırım süresinin sonunda doğmaktadır. ${ }^{67}$ Birleşme işleminin öncelikle yönetim kurulunda görüşülüp karara bağlanması ve sonrasında hedef şirket yönetim kurulu ile bir birleşme sözleşmesinin imzalanması gerekeceğinden, kanundaki yasağın uygulanacağı kabul edilirse birleşmenin görüşüldüğü yönetim kurulu toplantısına hiçbir üyenin katılmaması durumu doğabilir. Ancak ABD uygulamasında kurucular bu sebeple, ellerindeki kurucu payları açısından pay sahiplerine birleşmenin görüşüldüğü genel kurul toplantısında birleşmeye olumlu oy kullanacakları veya en azından çoğunluğun kararına göre oy kullanacaklarına yönelik oy sözleşmesi yapmaktadır. ${ }^{68}$

İzahnamede belirlenen süre sonunda, birleşme amaçlı ortaklık, ya hedef şirketle birleşerek faaliyete başlayacaktır ya da bu birleşme gerçekleşmezse, yatırımcılara halka arzdan toplanan gelirler iade edilerek ortaklık tasfiyeye girecektir. Birinci ihtimalde, birleşme işlemi tamamlanana kadar birleşme amaçlı ortaklığın pay sahiplerine herhangi bir temettü dağıtımı yapılmaz. ${ }^{69}$ Ayrıca bu ortaklığın birleşme gerçekleşene kadar herhangi bir aşamada tasfiye edilme riski mevcuttur; dolayısıyla bu risklerin izahnamede, yeteri kadar sayıda pay sahibinin genel kurulda birleşmeye olumlu oy kullanmaması durumunda birleşmenin gerçekleşmeyebileceğine ilişkin bir uyarı şeklinde yer alması gerekir. ${ }^{70}$ İkinci ihtimalde, birleşmenin gerçekleşmemesi ve ortaklığın tasfiyeye girmesi durumunda borsa fiyatı esas alınarak tasfiye işlemleri halledilebilir. Ancak emanet hesapta tutulan ve birleşme amacına özgülenen tutarın sadece para piyasalarında değerlendirilerek gönüllü geri alım programına ayrılması sebebiyle, ${ }^{71}$ bu ihtimalin düşük olduğunu söyleyebiliriz.

\section{B. GENEL KURUL ONAYI}

Birleşme amaçlı ortaklığın genel kurulunda, hedef şirket ve birleşme işlemi onaylanırsa, artık birleşmenin gerçekleşmesine bir engel bulunmamaktadır. Şüphesiz birleşmeye yeteri sayıda pay sahibinin olumlu oy vermesi gerekecektir, aksi halde birleşmenin gerçekleşmeme riski doğabilir. Böyle bir riskin bulunmadığı hallerde, TTK m. 136 vd. hükümlerinin uygulanması sonucu, genel kurul kararının tescil ve ilan edilmesiyle birleşme gerçekleşir. Birleşme amaçlı ortaklığın, birleşmeyi tamamlaması halinde artık diğer borsa şirketleri gibi işlem görmeye başlayacağ ${ }^{72}$ ve piyasa değerinin şirketin faaliyetlerine bağlı olarak değişebileceği unutulmamalıdır. ${ }^{73}$

67 Okutan Nilsson, 'Ortaklık' (n 2) 60-61.

68 Klausner, Ohlrogge and Ruan (n 14) 15-16. Ayrica bkz. Okutan Nilsson, 'Ortaklık' (n 2) 61 ve 197.

69 Altaş ( n 5) 21.

70 Bu hususa ilişkin bkz. aşa. "Birleşmenin Gerçekleşmemesi” başlığı altındaki açıklamalar.

71 Jenkinson and Sousa (n 5) 8-9; Altaş ( n 5) 20 ve 21. Ancak bu şirketlerin pay fiyatlarının, emanet hesaptaki pay başına düşen tutarın altında olduğu hallerde dahi, yatırımcının bir birleşmeyi onaylaması soncunda başarılı olmaması ihtimali yüksektir ve yine de bu halde, yatırımcının toplantıda birleşmeden yana olumlu oy kullandı̆̆ı ve kötü durumdaki SPAC’lerin dahi kolay kolay tasfiyeye girmedikleri belirlenmiştir, ayrıntılı bilgi için bkz. Jenkinson and Sousa (n 5) 19.

72 Coates (n 13); Okutan Nilsson, 'Structure' (n 5) 256.

73 ABD hukukunda, SPAC’lerin, birleşmeden sonra ticari hayatlarında başarılı olup olmadıkları üzerinde yapılan araştırmaya göre, birleşme sonrası başarı oranının yalnızca \%42 civarında kaldığı tespit edilmiştir; söz konusu çalışma ve ilgili sonuçlar için bkz. Vulanovic (n 1) $692 \mathrm{vd}$. 
Halka açı anonim şirket statüsünde olan birleşme amaçlı ortaklık açısından birleşme, SPKn m. 23/1-a ve Önemli Nitelikteki İşlem Tebliği m. 5/1-a uyarınca önemli nitelikteki işlem mahiyetindedir. Bu kapsamda, önemli nitelikteki işleme yönelik alınacak gerekçeli yönetim kurulu kararı ile bağımsız yönetim kurulu üyelerinin oylarının kamuya açıklanması gerekir. Ayrıca birleşmenin, önemli nitelikte işlem olmasının gereği, genel kurulda onaylanması için SPKn m. 29 ve Önemli Nitelikteki İşlemler Tebliği m. 7/1 uyarınca nitelikli nisaplar öngörülmüştür. Bir işlemin, önemli nitelikteki işlem olmasının pay sahibi açısından şüphesiz en önemli sonucu; pay sahibinin ayrılma hakkına sahip olmasıdır. Ancak Önemli Nitelikteki İşlemler Tebliği m. 12/1-i uyarınca birleşme amaçlı ortaklığın taraf olduğu birleşeme işlemlerinde ayrılma hakkının doğmayacağı açıkça öngörülmüştür. Bu kapsamda aşağıda inceleneceği üzere birleşme amaçlı ortaklık, birleşme işleminin görüşüleceği genel kurul toplantısında birleşmeye olumsuz oy veren pay sahibinin talebi üzerine, gönüllü geri alım işlemini uygulamalıdır.

Bir birleşme işleminin, halka açık anonim şirketin yönetim kontrolünün değişmesini sağlayacak şekilde yapılması karşısında, kural olarak kontrolü ele geçirecek oranda pay iktisap edenlerin, azınlıkta kalan diğer pay sahiplerine yönelik olarak zorunlu pay alım teklifinde bulunmaları da gerekir. Ancak birleşme amaçlı ortaklığın devralan sıfatıyla taraf olduğu birleşmelerde, Pay Alım Teklifi Tebliği m. 18/1-d uyarınca, ${ }^{74}$ SPKr bu yükümlülükten muafiyete karar verebilir. Nitekim birleşme amaçlı ortaklığın amacı, yönetim kontrolünün değişmesini sağlamaktır ${ }^{75}$ ve bu ortaklı̆̆ın pay sahiplerine yönelik başka bazı koruyucu mekanizmalar halihazırda mevzuatta öngörülmüştür. Ancak bu Tebliğ’de birleşme amaçlı ortaklığın devralan sıfatıyla birleşmeye katılmasına yapılan vurgu bazı tartışmaları beraberinde getirse de zorunlu pay alım teklifi muafiyeti açısından birleşme amaçlı ortaklığın, birleşmenin hangi tarafında olduğunun önem taşımaması gerekir. ${ }^{76}$ Dolayısıyla Önemli Nitelikteki İşlemler Tebliği m. 16/1-d hükmünde olduğu gibi birleşme amaçlı ortaklığın birleşme işlemine katılması, zorunlu pay alım teklifi muafiyet hali için yeterli görülmelidir.

Birleşmenin görüşüleceği genel kurul toplantısında, birleşmenin gerçekleşmesinde çok büyük menfaatleri olan ve pay sahibi sıfatını haiz yöneticilerin de oy kullanabileceğini söylemek gerekir. ${ }^{77}$ Nitekim TTK m. 436 uyarınca oydan yoksunluk hali, sadece pay sahibi ve ilgili kişiler ile şirket arasındaki kişisel nitelikte bir işlemin görüşülmesi durumunda ortaya çıkar. Ancak birleşme amaçlı ortaklığın hedef şirketle birleşme işleminin görüşülmesi, pay sahibi sıfatına sahip yönetici açısından kişisel nitelikteki bir iş olmamasından dolayı oydan yoksunluk halini oluşturmayacaktır. ${ }^{78}$

Bir borsa şirketiyle halka açık olmayan bir şirketin birleşmesi halinde, kapalı tip şirketin ortaklarının ellerindeki paylarını altı aylık bir süreyle borsada satmaları Birleşme Tebliği m. 13/6 uyarınca

74 Seri: II, No: 26.1 sayılı Pay Alım Teklifi Tebliği, RG 23.01.2014/28891.

75 Aynı görüşte bkz. Altan ve Acar ( n 2) s. 268.

76 Aynı doğrultuda bkz. Okutan Nilsson, 'Ortaklık' (n 2) 192; Aslan ( n 12) 91-92.

77 Türk sermaye piyasası hukukunda oydan yoksun pay kavramı ortadan kalkmıs ve sadece oy hakkını haiz paylar açısından bu hakkın kullanılamadığı bazı oydan yoksunluk halleri benimsenmiştir. Ancak ABD hukukunda SPAC’lerdeki sponsor payına sahip yöneticiler, genellikle B Grubu paylara sahiptir ve bu grubun özelliği gereği oy hakkına da sahip değildir, Gahng, Ritter and Zhang (n 6) 1.

78 Bu doğrultuda bkz. Okutan Nilsson, 'Ortaklık' (n 2) 197. 
yasaklanmıştır ve sonrasında da bu paylar için kademeli satış mümkün olacaktır. Ancak bu kısıtlama, aynı maddenin 8. fıkrası hükmü sebebiyle birleşme amaçlı ortaklıklar için uygulanmayacaktır. Dolayısıyla hedef şirket pay sahipleri, birleşme sonrasında paylarını istedikleri gibi borsada satabilecektir. Nitekim ABD hukukunda, birleşmeden önce şirkette pay sahibi olan kurumsal yatırımcıların, birleşmeden sonra tamamen şirketten çıktığını ve yerini yeni kurumsal yatırımcılara bıraktığ tespit edilmiştir. $^{79} \mathrm{Bu}$ noktada satışın hangi fiyat üzerinden yapılmasının bekleneceği düşünülebilir. ABD hukukunda, halka arzdan sonra SPAC’lerin payları, ilk halka arz fiyatı olarak en fazla 10 Dolar $^{80}$ ile oldukça yakın seviyede işlem görürken, 2020 yılının ikinci yarısında özellikle hedef şirketin elektronik aletlerle ilgili alanda faaliyet gösterdiği hallerde, birleşmenin açılanması sonucunda SPAC’lerin paylarının değerinin önemli şekilde arttı̆̆ 1 tespit edilmiştir. ${ }^{81}$ Yine de yapılan araştırmalar, bir SPAC’in birleşme sonrası ticari hayatına devam edebilmesi ihtimalinin beklenilenden daha az olduğunu göstermektedir. ${ }^{82}$ ABD hukukunda kendinden en az iki kat daha küçük ölçüde olan şirketlerle birleşmeye çalışan SPAC’lerin çok büyük bir oranının birleşmenin genel kurullarında onaylanmasında başarısız oldukları görülmüştür. ${ }^{83}$

\section{PAYLARDA SULANMA ETKISI}

Genel kurulda birleşme işlemi onaylandıktan sonra, birleşme amaçlı ortaklık, paylarında sulanma etkisi (dilution effect) ile karşılaşabilecektir. Özellikle halka açık anonim şirketin, birleşme oranının halka açık olmayan bir şirket lehine olduğu hallerde iki şirketin birleşmesinde, bu etki görülebilecektir. ${ }^{84}$ Birleşmenin gerçeklemesiyle, birleşme amaçlı ortaklığın kurucularının halka

79 Ignatyeva, Rauch and Wahrenburg (n 1) 67; Klausner, Ohlrogge and Ruan (n 14) 16. Bu durumun da farklı tür yatırımcı gruplarının, SPAC’in farklı yaşam döngüsü aşamasına ilgi duyuyor olabileceğini gösterdiğine yönelik olarak bkz. Ignatyeva, Rauch and Wahrenburg (n 1) 68.

80 Gahng, Ritter and Zhang (n 6) 1; Okutan Nilsson, 'Structure' (n 5) 254; Klausner, Ohlrogge and Ruan (n 14) 3. Sulanma etkisi dolayısıyla bu fiyat, yapılan bir araştırmaya göre birleşme duyurusun tarihinde ortalama 8 Dolar (bkz. Vulanovic (n 1) 686), birleşme sırasında da 6.67 Dolar olmaktadır (Klausner, Ohlrogge and Ruan (n 14) 57).

81 Saengchote (n 1) 5, nitekim yazar burada SPAC paylarının yanlış değerlendiğini (mispricing) belirtmektedir, bkz. Saengchote (n 1) 7-8. ABD'deki bir borsaya kote olmak istedikleri için daha iyi hazırlanmaları sebebiyle Çin menşeili bir şirketle birleşen SPAC’lerin ise daha başarılı olduğuna yönelik olarak bkz. Dimic, Lawrence and Vulanovic (n 5) 11. Diğer bir araştırmaya göre ise, Avrupa'daki SPAC’lerin birleşme için hedef şirketlerini enerji sektöründen seçtikleri tespit edilmiştir, Ignatyeva, Rauch and Wahrenburg (n 1) 69.

82 Vulanovic (n 1) 682; hatta bu performans düşüklügünün, tahmin edilenden çok daha kötü olduğuna yönelik olarak bkz. Dimitrova (n 1) 108. SPAC’lerin geleneksel halka arzla halka açılan şirketlere nazaran çok daha kötü bir performans gösterdikleri araştırmalarla tespit edilmiş ve hatta kötü performans gösteren şirketlerin daha çok SPAC’lerin dikkatini çektikleri için birleşmeden sonra hedef şirketler açısından "kurbağanın prense dönüşmediği (forgs turned prince scenario does not apply)" şeklindeki metaforla bu husus vurgulanmıştır, bkz. Kolb and Tykvová (n 35) 82 ve 93.

83 Berger (n 1) 74. Diğer taraftan, ABD hukukunda SPAC’lerin, çoğunlukla tek başına halka açılamayacak küçük firmalara bu fırsatı tanıdığı da belirtilmiștir, bkz. Kolb and Tykvová (n 35) 82 vd.

84 Manavgat (n 4) 583. Ayrıca ABD hukukunda payların halka arzında aracı kuruma ödenecek ücrette de bu etkinin görüldüğünden bahsedilmektedir. Şöyle ki, birçok SPAC’in paylarının birçoğu geri alıma konu edildiğinden, tüm payların halka arzı için en başta \%5,5 olan aracılık ücreti, geri alımdan sonra SPAC’te kalan örneğin \%50 olan paylara oranlarsak \%11'e çıkmaktadır. Bu durum da aracılık ücretinde geri alımın olmaması sebebiyle, aracı kurumun kazancının birleşmeden sonra sulanma etkisi sebebiyle oransal olarak arttığını göstermektedir, ayrıntılı bilgi için bkz. Klausner, Ohlrogge and Ruan (n 14) 21-22; diğer taraftan da bazı durumlarda halka arza aracılığa ilişkin ücretin tamamının, SPAC’in ancak başarılı bir şekilde hedef şirketle öngörülen bir yöntem kapsamında birleşmiş olması şartıyla ödeneceği 
arzdan önce sahip oldukları \%20'lik kurucu paylarının, halka arzdan sonra tabana yayılan sermaye karşısında değerlenmiş olması, bunun örneklerindendir. ${ }^{85}$

Birleşme amaçlı ortaklığın paylarında meydana gelebilecek sulanma etkisinin bazı şekillerde görülebilmesi mümkündür. Örneğin birleşme sırasında birleşme amaçlı ortaklığın hedef şirkete sağlayacağ 1 fonun miktarında ve ikinci olarak da birleşmede hedef şirketteki paylar için arttırılan sermaye ve birleşme amaçlı ortaklıkta, gönüllü geri alımdan sonra kalan payların fiyatında sulanma mümkündür. ${ }^{86}$ Dolayısıyla bir taraftan halka arzdan pay satın alan birleşme amaçlı ortaklığın pay sahipleri, hedef şirketin pay sahipleri ve kurucuların bu sulanmadan daha kârlı çıkmakta; ancak diğer taraftan bu sulanmanın bedelini nihai olarak, birleşme sonrasında hala birleşme amaçlı ortaklık paylarını elinde bulunduran pay sahipleri ödemektedir. ${ }^{87}$

Sulanma etkisi benzer şekilde, birleşmenin gerçekleşmesi sonucunda ortaklık varantlarının kullanılabilir hale gelmesi ile de görülebilecektir. ${ }^{88}$ Halka arz esnasında birleşme amaçlı ortaklıklar, ancak birleşmeden sonra kullanılabilir şekilde ${ }^{89}$ ortaklık varantları ihraç etmektedir. Buna göre birleşme amaçlı ortaklığın esas sözleşmesinde yer alan bir hüküm sayesinde, şirketin halka arz edilen paylarından tamamen bağımsız olarak sahibine, satın alma opsiyonu sunan bir sermaye piyasası aracıdır. ${ }^{90} \mathrm{Bu}$ varantların kullanılması da piyasada birleşme amaçlı ortaklığın paylarının değerinin düşmesine yol açacaktır.

\section{Ç. KOLAYLAŞTIRILMIŞ BIRLEŞME}

Kural olarak birleşmenin, kolaylaştırılmış usulde yapılması halinde, Birleşme Tebliği m. 13/2 uyarınca birleşme sözleşmesinin genel kurulda pay sahiplerinin onayına sunulmasına gerek kalmayacaktır. Bunun yanı sıra Önemli Nitelikteki İşlemler Tebliği m. 15/1-ç uyarınca kolaylaştırılmış birleşme durumunda ayrilma hakkı tanınmamakta, onun yerine zorunlu pay alım teklifinin yapılması öngörülmektedir. Nitekim kolaylaştırılmış birleşmede, ayrılma hakkının uygulanma şartları fiilen ortadan kalkmış olmaktadır. ${ }^{91}$ Buna göre, ayrılma hakkını kullanan pay sahibi, payını şirkete satıp şirketten çıkabilecekken, zorunlu pay alım teklifinde, pay sahibi payını, teklifi yapan pay sahibine satmaktadir.

kararlaştırıldığından, bu birleşmenin gerçekleşmesinde aracı kurumların da menfaati bulunmaktadır, Dimitrova (n 1) 102.

85 Jenkinson and Sousa (n 5) 8 vd.; Klausner, Ohlrogge and Ruan (n 14) 18; Kolb and Tykvová (n 35) 81; Ignatyeva, Rauch and Wahrenburg (n 1) 74; Okutan Nilsson, 'Structure' (n 5) 268-269.

86 Klausner, Ohlrogge and Ruan (n 14) 19.

87 Bu sebepledir ki, ABD’de SPAC'lerin hala çekici bir yatırım olduğu inanışının hakim olduğu düşünülmektedir, Klausner, Ohlrogge and Ruan (n 14) 39-40.

88 Okutan Nilsson, 'Structure' (n 5) 269; Ignatyeva, Rauch and Wahrenburg (n 1) 74; hatta gönüllü geri alım sebebiyle bu işleminin ardından da şirkette kalan paylarda bir sulanma etkisinin görüleceğine ilişkin bkz. Klausner, Ohlrogge and Ruan (n 14) 18-19.

89 Söz konusu varantlar (warrants), ABD hukukunda birleşmeden sonraki 5 yll sonra vadeli olarak ve 11.50 \$üzerinden satılmaktadır, Gahng, Ritter and Zhang (n 6) 1.

90 Ayrıntılı bilgi için bkz. Burak Adıgüzel, Sermaye Piyasası Hukuku (2. Baskı, Adalet, 2018) 200-201.

91 Okutan Nilsson, 'Ortaklık' (n 2) 183-184. 
Bu noktada tartışılması gereken husus, birleşmenin genel kurul onayına sunulmadığı kolaylaştırılmış usulde birleşmelerde, pay sahiplerinin birleşme işlemine onay vermeyerek paylarını şirkete satarak ayrılma haklarını nasıl kullanacaklarıdır. Birleşme amaçlı ortaklıklara ilişkin var olan düzenlemeler, birleşme kararının genel kurul onayından geçeceği üzerine kurgulandığından, kolaylaştırılmış birleşme dahi yapılsa, birleşme sözleşmesinin genel kurulda onaylanması gerektiği doktrinde belirtilmiştir. ${ }^{92}$ Ancak kolaylaştırılmış birleşmede amaç, sürecin hızlı ilerlemesi ve birleşme amacı ortaklığın, hali hazırda hedef şirketin \%95’inden fazlasına sahip hakim şirket statüsünü kullanması olduğu için, birleşme kararını tekrar genel kurul onayına sunmak, zaman, emek ve kaynak kaybına neden olabilecektir. Dolayısıyla kanaatimizce, pay sahibinin yönetim kuruluna başvurması suretiyle birleşmeye karşı olduğunu bir şekilde ispatlaması, gönüllü geri alım işleminin uygulanması için yeterli olmalıdır, ki bu uygulama birleşme amaçlı ortaklık yapısına ve yatırımcının korunması ilkesine daha uygundur. ${ }^{93}$

\section{BIRLEŞMENIN GERÇEKLEŞMEMESi}

Birleşme amaçlı ortaklığın halka arz esnasında izahnamesinde açıkladığı süre içinde birleşmenin herhangi bir sebeple gerçekleşmemesi durumunda, varantların bir değeri kalmayacak ${ }^{94}$ ve halka arz gelirlerinin en az \%90’ının depo edildiği hesapta var olan miktarın kurucular dışındaki pay sahiplerine iadesi söz konusu olacaktır. Şirketin tasfiyesi ile yapılacak söz konusu iade, paylar itfa edilerek sermayenin azaltılması yoluyla oransallık ilkesine göre gerçekleştirilebilir. ${ }^{95}$

Hedef şirketin açıklanmasını müteakip genel kurulda birleşme kararının oylanması tarihinde yeteri sayıda pay sahibinin (conversion threshold) birleşme için olumlu oy kullanmaması halinde birleşme gerçekleşemeyebilir. ${ }^{96}$ Dolayısıyla ABD hukukunda SPAC’ler, izahnamesinde açıklayacağ gönüllü geri alım programında, gönüllü geri alıma konu edilebilecek payların oranına ilișkin, \%10'dan az olmamak üzere bir sınır belirlemek hakkını haizdir. ${ }^{97}$ Ancak Türk hukukunda bu yönde bir sınır getirebilme imkanının Birleşme Tebliği’nde verilen tanımda yer almaması, düzenlemenin amacının geri alım sınırının belirlenmesine izin verilmediği yönündeki kanaati güçlendirmiştir. ${ }^{98}$ Ancak geri alım programı uygulanırken TTK m. 480/3’te emredici nitelikte düzenlenen sermayenin iadesi yasağı

92 Okutan Nilsson, 'Ortaklık' (n 2) 196.

93 ABD hukukunda özellikle, önceden genel kurul toplantısının yapılmasını zorunlu tutan hüküm 2009-2010 yılında değiştirilmiş ve artık şirketlerin, genel kurul toplantısının yapılması yerine, genel bir pay alım teklifi yapılması ile yatırımcıya şirketten çıkma imkanının verilmesi yeterli görülmeye başlanmıştır, bkz. Kolb and Tykvová (n 35) s. 91. Bu uygulamanın Türk hukukunda da kabul edilmesinin, birleşme amaçlı ortaklık yatırımcısının menfaatlerini korumaya daha çok hizmet ettiği belirtilmiştir, bkz. Okutan Nilsson, 'Ortaklık' (n 2) 195-196.

94 Dimitrova (n 1) 102.

95 Gahng, Ritter and Zhang (n 6) 2; Manavgat (n 4) 585; Altaş (n 5 ) 23.

96 Okutan Nilsson, 'Structure' (n 5) 258. Hangi sayının, birleşmenin gerçekleşmesini engelleyecek kadar fazla olduğu ise birleşme amaçlı ortaklığın sermayesine göre belirlenecektir. Bu oran, genel olarak ABD hukukunda \%30-40 olarak belirtilmektedir, Berger (n 1) 71; söz konusu oranın \%20 olduğuna yönelik bkz. Jenkinson and Sousa (n 5) 8; Dimitrova (n 1) 103 .

97 Benzer ifadelerin kullanıldığı ilgili mevzuat için bkz. NASDAQ Listing Rules, IM-5101-2 (2)(d) ve NYSE Listed Company Manual, 102.06 (4)(b). Bu hükümlere ‘bulldog provisions' adı verilmektedir, bkz. Okutan Nilsson, 'Structure' (n 5) 259. 
da ihlal edilmek suretiyle şirketin sonunu getirme durumu ortaya çıkmamalıdır. Geri alım işleminde kullanılacak tutarın, geri alıma tabi tutulacak payların fazlalığı nedeniyle yüksek olması halinde, şirketin geri alımdan sonra tasfiyesi söz konusu olmayacak ise, bu tutarın şirketin sermayesinden karşılanmaması gerekir. ${ }^{99}$ Şirketin tasfiyeye başlaması halinde, şüphesiz birleşme amaçlı ortaklığın piyasa değeri düşecektir. ${ }^{100}$

ABD hukukunda SPAC pay sahiplerinin belirli bir oranının şirketten ayrılması imkânı olmasına rağmen, diğer taraftan bu durumda, SPAC’in malvarlığının belirli bir tutarın altına inmesi şartıyla, hedef şirkete birleşme sözleşmesini fesih imkânı tanınmaktadır. ${ }^{101}$ Benzer bir hak, Türk hukukunda da birleşme sözleşmesine bu yönde bir hüküm koyulmak suretiyle hedef şirkete tanınabilir. ${ }^{102}$

\section{Ç. GÖNÜLLÜ GERI ALIM IŞLEMI}

\section{DAYANAĞI}

Birleşmenin, önemli nitelikteki işlemlerden olması sebebiyle, pay sahipleri kural olarak SPKn m. 24 uyarınca ayrılma hakkının kullanımı ile korunmuştur. Benzer doğrultuda birleşme amaçlı ortaklıklar açısından, ayrılma hakkı yerine, birleşmenin onaya sunulduğu genel kurul toplantısında birleşmeye olumsuz oy veren pay sahiplerinin şirkete paylarını satıp çıkma hakkı (conversion or redemption right) bulunmaktadır. Bu durumda şirket, kendisi açısından zorunlu ${ }^{103}$ ama pay sahibi açısından gönüllülük esasına dayalı gönüllü geri alım programı ${ }^{104}$ kapsamında geri alım gerçekleştirmek zorundadır; ancak söz konusu alımlara Geri Alınan Paylar Tebliği hükümleri uygulanmayacaktır. ${ }^{105}$

Geri Alınan Paylar Tebliği m. 4/1-g hükmündeki tanımdan da açıkça anlaşılacağg üzere, gönüllü geri alım programının izahnamede esas ve usullerinin belirtilerek düzenleneceği açıktır. Bu durumda izahnamenin onaylanması müessesesi ile gönüllü geri alım esaslarının SPKr gözetim ve denetimine tabi olacağını düşünmek sermaye piyasası hukuku düzenlemelerine ilk bakışta daha uygun

99 Bu noktada Okutan Nilsson, Geri Alınan Paylar Tebliği hükümleri birleşme amaçlı ortaklıkların yaptığı geri alımlar için uygulanmayacak olsa dahi TTK m. 480/3 hükmüne riayet edilmesi gerektiğini vurgulamaktadır, Okutan Nilsson, 'Ortaklık' (n 2) 213-214.

100 Ancak araştırmalar, birleşmeden önce emanet hesaptaki tutara yakın seyreden pay fiyatlarının, birleşmenin gerçekleşmesi halinde, satın alma aşamasında, şirketin değerinin, bu hesapta tutulan ve şirketin birleşmeye ayırdığı tutarın üzerine çıktığını göstermiştir, bkz. Jenkinson and Sousa (n 5) 7.

101 Okutan Nilsson, 'Ortaklık' (n 2) 211.

102 Benzer yönde görüş için bkz. Okutan Nilsson, 'Ortaklık' (n 2) 211.

103 Ölekli (n 12) 234; Okutan Nilsson, 'Ortaklık' (n 2) 199.

104 Geri Alınan Paylar Tebliği m. 4/1-g uyarınca gönüllü geri alım programı, "Birleşme amaçh ortaklığın taraf olduğu birleşme işleminin onaylandiğı genel kurul toplantısında olumsuz oy kullanan pay sahiplerine veya birleşme amaçlı ortaklğın sona ermesi durumunda kurucular dışındaki tüm pay sahiplerine ait payların halka açılma nedeniyle düzenlenen izahnamede belirtilen esas ve usuller çerçevesinde belirlenen fiyatlar üzerinden satın alınmasina imkân veren programi" ifade etmektedir.

105 Bu tebliğin birçok hükmünün, birleşme amaçlı ortaklığa uygulanabilecek nitelikte olmaması, birleşme amaçlı ortaklık tarafından yapılan gönüllü geri alımın, şirketin paylarının fiyatlarını düzeltmek veya piyasadaki düşüşten şirketi korumak gibi bir amacının bulunmaması bu durumun sebebi olarak gösterilebilir, bkz. Okutan Nilsson, 'Ortaklık' (n 2) 198-199. Nitekim yazar, payların satın alınması yükümlülüğünü, Geri Alınan Paylar Tebliği kapsamında yapılan geri alımdan ziyade ayrılma hakkına benzetmektedir, bkz. Okutan Nilsson, 'Ortaklık' (n 2) 199. 
görünmektedir. ${ }^{106}$ Ancak SPKn m. 6 ve İzahname Tebliği m. 22/1 uyarınca SPKr’nun izahnamenin onaylanması aşamasında izahnameye ilişkin yapacağı denetim, kapsamlı bir içerik denetimi olmayıp izahnamede yer alan bilgilerin tutarlı, anlaşılabilir ve belirlenen standartlara göre eksiksiz olmasıla oldukça sınırlı kalacaktır. Dolayısıyla SPKr, izahnamenin onaylanması aşamasında, esasen gönüllü geri alım programının yatırımcının korunmasına ne kadar uygun olduğuna veya adil olduğuna ilişkin herhangi bir müdahalede bulunamayacaktır. Sonuç olarak birleşme amaçlı ortaklıkların en önemli özelliklerinden olan pay sahibine gönüllü geri alım yoluyla tanınan ayrılma hakkının veya benzer şekildeki yatırımının iadesi talebinin kullanımı önemli ölçüde baltalanmıştır.

Gönüllü geri alım hakkını herhangi bir sebeple kullanmayan, birleşmenin görüşüldügü genel kurul toplantısını bir sebeple kaçıran veya bu toplantıda birleşmeye olumsuz oy vermeyen pay sahibinin her zaman elindeki payını borsada satma imkânı bulunmaktadır. Tabi pay sahibinin, bu durumda payını yalnızca, piyasa fiyatının, gönüllü geri alım fiyatının üzerine çıktığı durumlarda satacağı açıktır. ${ }^{107}$

\section{BU IŞLEME TABI TUTULACAK PAYLAR}

Türk hukukunda birleşmeye genel kurulda olumsuz oy kullanan pay sahibi, ayrıca muhalefetini tutanağa geçirtmeye gerek kalmaksızın paylarını birleşme amaçlı ortaklığın satın almasını talep edebilir. ABD hukukunda ise durum biraz farklıdır; yatırımcının, birleşmeye olumlu oy kullanmasına rağmen yine de gönüllü geri alım hakkını kullanarak şirketten ayrılma hakkı mevcuttur. ${ }^{108}$ Ayrıca birleşmenin oylandığı genel kurul toplantısına herhangi bir sebeple katılamamış pay sahiplerinin de Önemli Nitelikteki İşlemler Tebliği m. 9/2'deki düzenlemeye paralel şekilde satma hakkını kullanmasına izin verilmesi gerekir. ${ }^{109}$ Geri alma işleminin tam olarak nasıl yapılacağı hususunda da Önemli Nitelikteki İşlemler Tebliği hükümlerinden faydalanabilirse de satma hakkını kullanmak isteyen bir pay sahibinin, ayrılma hakkının kullanılmasında olduğu gibi elindeki payların tamamını satarak şirketten ayrılmaya zorlanması yerine yatırımının dilediği kadarını şirketten çekmesine müsaade edilmesi gerekir. ${ }^{110}$

Birleşme Tebliği’nde verilen tanıma göre, geri alım işlemi, paya veya sermaye oranına göre değil; pay sahiplerine yönelik olarak yapılacaktır. Dolayısıyla bir pay sahibinin TTK m. 434/2 uyarınca oy hakkının sınırlanması yoluyla geri alım işlemine tabi payın sınırlandırılmasının mümkün olup olmadığı da bu noktada düşünülebilir. Ancak geri alım işleminin, bir birleşme amaçlı ortaklığa daha en başta güvenip sermayesini koyan ve sonrasında hedef şirket seçiminden memnun kalmayan pay

106 Okutan Nilsson, 'Ortaklık' (n 2) 202.

107 Klausner, Ohlrogge and Ruan (n 14) 18; Gahng, Ritter and Zhang (n 6) 3 ve 31.

108 Söz konusu bu husus, 2010 yılında yapılan bir değişiklikle ABD hukukuna girmiştir, ayrıntılı bilgi için bkz. Gahng, Ritter and Zhang (n 6) 11.

109 Aynı doğrultuda bkz. Okutan Nilsson, 'Ortaklık' (n 2) 207.

110 Okutan Nilsson, 'Ortaklık' (n 2) 208. 
sahibine yönelik olması sebebiyle, oy hakkı esas sözleşme ile sınırlandırılmış olsa dahi pay sahibinin, tüm paylarına yönelik olarak bu hakkını kullanabilmesi daha uygundur. ${ }^{111}$

Geri alım işlemine tabi tutulacak payların, halka arzda edinilen paylar olması gerektiğini; kurucu payları olarak adlandırabileceğimiz ve halka arzdan önce kurucular tarafından halk arz fiyatına kıyasla çok düşük kalan nominal değerlerde edinilen payların bu alım işlemine konu olmayacağını belirtmeliyiz. ${ }^{112}$ Nitekim ilk etapta kurucuların elinde bulunan bu hisseler, sonrasında başka yöneticilere de aktarılabilir veya kurucular ile yöneticiler ellerinde halihazırda bulunan kurucu payları dışında, halka arzdan da bazı payları edinebilirler. Dolayısıyla, geri alım işlemine tabi olmayan payları belirlerken, kurucuların elindeki paylardan ziyade, şirketin kuruluşunda kurucular, sponsorlar veya yöneticiler elinde bulunabilecek ve halka arzdan önce nominal değer üzerinden edinilmiş olan 'kurucu payları (sponsor promotes)' olarak adlandırılan payları esas almak daha doğru olacaktır. Kurucu dahi olsa, halka arzda, arz fiyatı üzerinden edinilen paylara ilişkin gönüllü geri alım hakkının kullanılması mümkündür.

\section{GÖNÜLLÜ GERI ALIM FIYATI}

Birleşmeye olumsuz oy kullanıp şirketten ayrılmak isteyen pay sahipleri ile birleşmenin gerçekleşmemesi durumunda yatırımlarını geri almak isteyen pay sahiplerinin paylarının hangi fiyatla geri alınacağı mevzuatta açık bir şekilde düzenlenmemiştir. ABD hukukunda birleşmenin gerçekleşmesi durumunda, genel kurulda birleşmeye olumsuz oy kullanan veya olumlu oy kullanmış olsa da şirketten ayrılmak isteyen pay sahiplerine, emanet hesaptaki vergiler ve işletme giderleri düşüldükten sonra kalan toplamdan payları oranında hesaplama yapılıp kendilerine gereken miktar verilmektedir. ${ }^{113}$ Türk hukukunda bu hususta Birleşme Tebliğỉnde, “...birleşme işleminin onaylandiğ genel kurul toplantısında olumsuz oy kullanan pay sahiplerine... kurucular dışındaki tüm pay sahiplerine ait paylara yönelik olarak gönüllü geri alım işlemini izahnamede belirtilen esaslar çerçevesinde gerçekleştirecek olan...” ve Kotasyon Yönergesi m. 24’te “...halka arz gelirinin nemalandırılmış toplam tutarının en az \%80'ini kullanarak bir şirketle birleşmemesi halinde...” ortaklığın kottan çıkarılacağ belirtilmiştir. $\mathrm{Bu}$ düzenlemelerin ötesinde herhangi bir düzenleme bulunmamakla birlikte, kanaatimizce aynı yöntem Türk hukukunda da uygulanabilir.

111 Okutan Nilsson, 'Ortaklık' (n 2) 209. Yazar, eski 2499 sayılı SPKn döneminde var olan oydan yoksun paylara ilişkin benzer bir tartışmanın, önemli nitelikte işlemlere ilişkin ayrılma hakkında da gündeme geldiğini ve öğretideki baskın görüşün, genel kuruluna gelip muhalefet ettikleri takdirde, ayrılma hakkını kullanabilecekleri yönünde olduğunu belirtmektedir, bkz. Okutan Nilsson, 'Ortaklık' (n 2) 210, dn. 555.

112 Kurucu payları, halka arz edilen payların \%20'si kadardır ve birleşmenin gerçekleşmemesi halinde değerini yitirirler. Ayrıca kurucu payları, nominal değer üzerinden oldukça düşük bir fiyata edinildiği ve sponsorların aslen birleşme projesinin yükünü taşıması gereken kişiler olduğu göz önüne alınırsa (Dimitrova (n 1) 102), bu kimselerin paylarını satarak şirketten çıkmalarına izin verilmemesi oldukça yerindedir, bkz. Okutan Nilsson, 'Ortaklık' (n 2) 87; Aslan ( n 12) 88.

113 NASDAQ Listing Rules, IM-5101-2 (2)(d) ve NYSE Listed Company Manual, 102.06 (4)(b) bu yönde aynı ifadeleri kullanmaktadir: "... to a pro rata share of the aggregate amount then on deposit in the trust account (net of taxes payable, and amounts disbursed to management for working capital purposes)...”. Ayrıca bkz. Vulanovic (n 1) 685; Jenkinson and Sousa (n 5) 8; bu miktarın içinde emanet hesaptaki paranın fazi getirisi de bulunmaktadır, Klausner, Ohlrogge and Ruan (n 14) 7. 
Bu noktada tartışılması gereken diğer bir husus, belirli yatırım araçlarında değerlendirilen ve halka arzdan elde edilen gelirin \%90'ının, doğrudan mı yoksa elde edilen semerelerle birlikte mi iade edileceğidir. Burada belirlenecek görüşe göre, gönüllü geri alım fiyatı değişiklik gösterebilecektir. İlk ihtimalde, birleşmenin gerçekleşmemesi veya gerçekleşse dahi bazı yatırımcıların bu birleşmeye katılmak istememesi halinde, kurucular dışında kalan ve halka arzdan pay edinen yatırımcılar, pay oranlarıyla paralel bir şekilde emanet hesaba ilk aşamada yatırılan tutarı alacaktır. Bu tutar, birleşme amaçlı ortaklığın halka arzdan elde ettiği fonun en az \%90’nın yatırıldığı emanet hesaptaki tutardır. İlk ihtimalde bu tutarın paylara oranlanması ile bulunacak miktar, şirketten ayrılmak isteyen pay sahibine iade edilebilecektir.

Halka arz gelirlerinin \%90’nın tutulduğu emanet hesaplardaki tutarın, izahnamede açıklanacak bir nakit yönetim politikası çerçevesinde Birleşme Tebliğinde verilen tanıma göre mevduat, devlet iç borçlanma senedi ve benzeri yatırım araçlarında değerlendirilmesi, nemalandırılması öngörülmektedir. Birleşme amaçlı ortaklığın halka arzı ile birleşme kararının oylanmasından sonra pay sahibinin şirketten ayrılmak istemesi arasındaki zaman farkı düşünüldüğünde, emanet hesaptaki tutarın, bu yatırımlarla büyük ihtimalle artmış olabileceğini söyleyebiliriz. ${ }^{114}$ Nitekim Tebliğ'de sayılan mevduat, devlet iç borçlanma senetleri gibi yatırım araçlarının düşük riskli araçlar olduğu ${ }^{115}$ ve bunlara yatırım yapılması halinde belirli bir getirinin olacağını düşününce emanet hesaptaki miktar artacaktır. Bu fazlalığın da pay sahiplerine, payları oranında dağıtılıp dağıtılmayacağı; dağıtılmayacaksa, bu fazlalığın tasfiyeye mi dahil edileceği Birleşme Tebliği’nde açık bir şekilde belirtilmemiştir. Ancak yine ilgili tebliğdeki tanım göz önüne alındığında, düzenlemenin amacının, halka arzdan elde edilen gelirin en az \%90'lık kısmının, yani emanet hesapta tutulan bu kısmın vergiler gibi zorunlu giderler düşüldükten sonra tamamının kurucular dışındaki pay sahiplerine iade edilmesi olduğu anlaşılabilir. ${ }^{116}$ Sonuç olarak kanaatimizce ikinci ihtimaldeki hesaplama yöntemi birleşme amaçlı ortaklığın yapısına daha çok uygundur ve halka arz gelirinin \%90’nın tutulduğu emanet hesaplardaki toplam miktardan işletme giderleri ve vergiler düşüldükten sonra kalan tutarının, kurucu payları dışındaki paylara, pay oranında bölünmesi ile elde edilecek pay başına hesaplanan rakam, gönüllü geri alım fiyatı olmalıdır.

\section{SONUÇ}

Birleşme amaçlı ortaklıklar, Türk hukukuna 2013 yılında girmiştir ve II-23.2 sayılı Birleşme ve Bölünme Tebliği m. 4/1-b’de tüm özellikleriyle tanımlanmıştır. Buna göre birleşme amacı ortaklığın

114 Jenkinson and Sousa (n 5) 6. Nitekim uygulamada da yatırımcıların ortaya koydukları anaparaya denk gelen veya yakın bir tutarı geri alabildikleri de belirtilmiştir, bkz. Altaş ( n 5) 21.

115 Aslan ( n 12) 87.

116 Okutan Nilsson, 'Ortaklık' (n 2) 82-83. ABD hukukunda SPAC uygulamasının da bu yönde olduğuna dair bkz. Jenkinson and Sousa (n 5) 8; Anand (n 1) 21; Berger (n 1) 75. Nitekim NASDAQ Listing Rules, IM-5101-2 (2)(e) ve NYSE Listed Company Manual, 102.06 (4)(c) bu durumda, emanet hesaptaki tutardan vergi ve işletme giderleri düşüldükten sonra kalan toplamdan pay oranlarına göre pay sahiplerine paylarını şirkete satıp paralarını geri alarak şirketten ayrılma imkanı getirilmiştir: "... the opportunity to redeem all their shares for cash equal to their pro rata share of the aggregate amount then in the deposit account (net of taxes payable, and amounts disbursed to management for working capital purposes)...”. 
nihai amacı, halka açı olmayan, ticari faaliyeti olan bir şirket ile birleşmektir. Bu doğrultuda hedef şirketin, ortaklığın halka arzı esnasında belirli olmaması gerekmekte; hedef şirkete ilişkin izahnamede sadece ülkesel veya sektörel bir belirleme yapılması kabul edilmektedir. Hedef şirketler açısından geleneksel halka arzdan ziyade birleşme amaçlı ortaklık ile halka açılmak, piyasa riskinin olmaması, çok tecrübeli ve kaliteli bir yönetim ekibi ile çalışma imkanı, ciddi miktarda hazır bir fonun bulunması gibi sebeplerden dolayı, daha avantajlı olabilir.

Birleşmenin azami hangi süre içinde gerçekleşmesi gerektiği sorusu Türk hukukunda mevzuatta net bir şekilde yanıtlanmamıştır. Buna göre BİST Kotasyon Yönergesi m. 24’te azami 24 ay veya izahnamede öngörülecek bir süre içinde birleşme işleminin gerçekleşmesi aranmıştır. Sonuç olarak birleşme amaçlı ortalığın, birleşme açısından azami süreyi izahnamesinde göstermek suretiyle belirleme hususunda serbestiye sahip olduğu düşünülebilir. Ancak bu sürenin uzun tutulması, pay sahipleri nezdinde olumsuz bir kanaatin oluşmasına sebep olmaktadır. Sürenin sonuna gelinmesine rağmen hedef şirketin açılanmaması halinde ise, finansal açıdan ortaklık varantları ve kurucu payları sebebiyle ortaklı̆̆ın başarısına oldukça bağlanan yöneticilerle, ortaklığın pay sahipleri arasında bir menfaat çatışması yaşanabilir ve bu durum yöneticilerin ne pahasına olursa olursun birleşmeyi gerçekleştirmesine, örneğin ortaklığın, kendisine uzun vadede yarar sağlamayacak bir hedef şirketle birleşmesine yol açabilir.

Birleşmenin görüşüleceği genel kurul toplantısında, yeteri sayıda pay sahibinin olumlu oy kullanmaması sonucunda birleşme gerçekleşmeyebilir. Ancak hangi oranda olumlu oyun birleşme açısından gerektiğine ilişkin Türk hukukunda bir hüküm bulunmamaktadır. Birleşme Tebliğinnde verilen tanımda bu orana ilişkin herhangi bir sınırın yer almaması sebebiyle, gönüllü geri alıma ilişkin pay sahiplerine yönelik bir sınırın uygulanmaması gerekmektedir. Genel kurulda birleşme işlemi onaylanırsa, bundan sonra \%20'lik kurucu paylarının, halka arzdan sonra tabana yayılan sermaye karşısında değerlenmiş olması veya ortaklık varantlarının kullanılabilir hale gelmesi sonucunda birleşme amaçlı ortaklığın paylarında sulanma etkisi görülebilecektir.

Birleşme amaçlı ortaklık açısından önemli nitelikteki işlem olan birleşmede, Önemli Nitelikteki İşlemler Tebliği m. 12/1-i uyarınca ayrılma hakkı doğmamaktadır. Bu kapsamda birleşme amaçlı ortaklık, ayrılma hakkı yerine birleşmeye olumsuz oy veren pay sahibinin talebi üzerine, gönüllü geri alım işlemini uygulamalıdır. Genel kurulda olumsuz oy kullanan veya bir sebeple toplantıya katılamayan pay sahibinin de, muhalefetini tutanağa geçirtmeye gerek kalmaksızın bu hakkını kullanabilmesi uygun olacaktır.

Geri Alınan Paylar Tebliği m. 4/1-g uyarınca, gönüllü geri alım programının izahnamede esas ve usullerinin belirtilmesi gerekir. Gönüllü geri alma işleminde, pay sahibinin, yatırımının dilediği kadarını şirketten çekmesine müsaade edilmesi gerekir. Geri alım işlemine tabi tutulacak paylar kurucu payları dışında kalan ve dolayısıyla halka arzda edinilen paylardır. Gönüllü geri alım fiyatı, halka arz gelirinin \%90’ının tutulduğu emanet hesaptaki vergiler ve işletme giderleri düşüldükten sonra kalan toplamdan, ilgili pay sahibinin payları oranında yapılan hesaplama ile belirlenir. 


\section{KAYNAKÇA}

Adıgüzel B, Sermaye Piyasası Hukuku (2. Baskı, Adalet 2018).

Altan D ve Acar N, 'Yeni Bir Alternatif Yatırım Aracı: Birleşme Amaçlı Ortaklıklar' (2014) 16(1) Dokuz Eylül Üniversitesi Hukuk Fakültesi Dergisi 251-268.

Altan D, Ayanlar E, Küreğibüyük E ve Ünlü Ş, 'Nedir Bu SPAC?', (GKC Partners, Sermaye Piyasaları Bülteni, 11 Ocak 2020) 1-4.

Altaş G, 'Satın Alma Amaçlı Şirketler' (2012) 120 TSPAKB Gündem 18-29.

Anand N, 'Special Purpose Acquisition Company' (2020) 7(4) Court Uncourt 21-22.

Aslan M, 'Sermaye Piyasası Kanunu’na Göre Şirket Birleşmeleri' (Yüksek Lisans Tezi, Bahçeşehir Üniversitesi 2018).

Bai J, Ma A and Zheng M, 'Reaching for Yield in the Going-Public Market: Evidence from SPACs' (SSRN, 2021) <https://ssrn.com/abstract=3746490> Erişim Tarihi 01 Eylül 2021.

Berger R, 'SPACs: An Alternative Way to Access the Public Markets' (2008) 2(3) Journal of Applied Corporate Finance 68-75.

Coates J, 'SPACs, IPOs and Liability Risk under the Securities Law' (SEC Public Statement, 8 April 2021) <https:// www.sec.gov/news/public-statement/spacs-ipos-liability-risk-under-securities-laws $>$ Erişim Tarihi 25 Mayis 2021.

Dimic N, Lawrence E and Vulanovic M, 'The Determinants of IPO Withdrawals: Evidence from SPACs' (SSRN, 2020) 1-31, <https://ssrn.com/abstract=3538671> Erişim Tarihi 06 Eylül 2021.

Dimitrova L, 'Perverse Incentives of Special Purpose Acquasition Companies, 'the Poor Man's Private Equity Funds” (2017) 63 Journal of Accounting and Economics 99-120.

Gahng M, Ritter JR and Zhang D, 'SPACs' (SSRN, 2021) 1-64, <https://ssrn.com/abstract=3775847> Erişim Tarihi 06 Eylül 2021.

Ignatyeva E, Rauch C and Wharenburg M, 'Analysing European SPACs' (2013) 17(1) The Journal of Private Equity 64-79.

Jenkinson T and Sousa, M 'Why SPAC Investors Should Listen to the Market' (SSRN, 2009) <https://ssrn.com/ abstract=1331383 > Erişim Tarihi 20 Haziran 2021.

Kolb J and Tykvová T, 'Going Public via Special Purpose Acquisiation Companies: Frogs do not Turn into Princes' (2016) 40 Journal of Corporate Finance 80-96.

Klausner M, Ohlrogge M and Ruan E, 'A Sober Look at SPACs' (European Corporate Governance Institution, Finance Working Paper Series, N. 746/2021) <http://ssrn.com/abstract_id=3720919> Erişim Tarihi10 Temmuz 2021.

Manavgat Ç, Hukuki Bakımdan Halka Açık Anonim Ortaklıklar ve Halka Arz (BTHAE 2016).

Okutan Nilsson G, 'Incentive Structure of Special Purpose Acquisition Companies' (2018) 19 European Business Organisation Law Review 253-274. (Anılış: Structure)

Okutan Nilsson G, Sermaye Piyasası Hukukunda Birleşme Amaçlı Ortaklık (On İki Levha 2016). (Anılış: Ortaklık)

Ölekli N, 'Halka Açık Anonim Ortaklıklarda Ayrılma Hakkı', (2018) 76/2 İstanbul Hukuk Mecmuası 221-256.

Saengchote K, 'The Tesla Effect and the Mispricing of Special Purpose Acquisition Companies (SPACs)' (SSRN, 2021) https://ssrn.com/abstract=3800323 Erişim Tarihi 06 Haziran 2021, s. 1-11.

Turanlı H, Yeni Türk Ticaret Kanunu’na Göre Ticaret Şirketlerinin Birleşmesi (Orion 2014).

Vulanovic M, 'SPACs: Post-Merger Survival' (2017) 43(6) Managerial Finance 679-699. 